\title{
Actual evapotranspiration and precipitation measured by lysimeters: a comparison with eddy covariance and tipping bucket
}

\author{
S. Gebler, H.-J. Hendricks Franssen, T. Pütz, H. Post, M. Schmidt, and H. Vereecken \\ Agrosphere Institute (IBG-3), Forschungszentrum Jülich, 52425 Jülich, Germany \\ Correspondence to: S. Gebler (s.gebler@fz-juelich.de) \\ Received: 31 October 2014 - Published in Hydrol. Earth Syst. Sci. Discuss.: 17 December 2014 \\ Revised: 2 April 2015 - Accepted: 7 April 2015 - Published: 5 May 2015
}

\begin{abstract}
This study compares actual evapotranspiration $\left(\mathrm{ET}_{\mathrm{a}}\right)$ measurements by a set of six weighable lysimeters, $\mathrm{ET}_{\mathrm{a}}$ estimates obtained with the eddy covariance (EC) method, and evapotranspiration calculated with the full-form Penman-Monteith equation (ET $\mathrm{EPM}_{\mathrm{PM}}$ ) for the Rollesbroich site in the Eifel (western Germany). The comparison of $\mathrm{ET}_{\mathrm{a}}$ measured by EC (including correction of the energy balance deficit) and by lysimeters is rarely reported in the literature and allows more insight into the performance of both methods. An evaluation of $\mathrm{ET}_{\mathrm{a}}$ for the two methods for the year 2012 shows a good agreement with a total difference of $3.8 \%$ $(19 \mathrm{~mm})$ between the $\mathrm{ET}_{\mathrm{a}}$ estimates. The highest agreement and smallest relative differences $(<8 \%)$ on a monthly basis between both methods are found in summer. $\mathrm{ET}_{\mathrm{a}}$ was close to $\mathrm{ET}_{\mathrm{PM}}$, indicating that ET was energy limited and not limited by water availability. $\mathrm{ET}_{\mathrm{a}}$ differences between lysimeter and EC were mainly related to differences in grass height caused by harvest and the EC footprint. The lysimeter data were also used to estimate precipitation amounts in combination with a filter algorithm for the high-precision lysimeters recently introduced by Peters et al. (2014). The estimated precipitation amounts from the lysimeter data differ significantly from precipitation amounts recorded with a standard rain gauge at the Rollesbroich test site. For the complete year 2012 the lysimeter records show a $16 \%$ higher precipitation amount than the tipping bucket. After a correction of the tipping bucket measurements by the method of Richter (1995) this amount was reduced to $3 \%$. With the help of an onsite camera the precipitation measurements of the lysimeters were analyzed in more detail. It was found that the lysimeters record more precipitation than the tipping bucket, in part related to the detection of rime and dew, which contribute $17 \%$ to the yearly difference between both methods. In ad-
\end{abstract}

dition, fog and drizzle explain an additional $5.5 \%$ of the total difference. Larger differences are also recorded for snow and sleet situations. During snowfall, the tipping bucket device underestimated precipitation severely, and these situations contributed also $7.9 \%$ to the total difference. However, $36 \%$ of the total yearly difference was associated with snow cover without apparent snowfall, and under these conditions snow bridges and snow drift seem to explain the strong overestimation of precipitation by the lysimeter. The remaining precipitation difference (about $33 \%$ ) could not be explained and did not show a clear relation to wind speed. The variation of the individual lysimeters devices compared to the lysimeter mean are small, showing variations up to $3 \%$ for precipitation and $8 \%$ for evapotranspiration.

\section{Introduction}

Precise estimates of precipitation and actual evapotranspiration are important for an improved understanding of water and energy exchange processes between land and atmosphere relevant for many scientific disciplines and agricultural management. Information about measurement errors and uncertainties is essential for improving measurement methods and correction techniques as well as for dealing with uncertainty during calibration and validation of model simulations. Although first devices for modern scientific purposes were developed in Europe during the 17th century (Kohnke et al., 1940; Strangeways, 2010), the accurate estimation of precipitation $(P)$ and actual evapotranspiration $\left(\mathrm{ET}_{\mathrm{a}}\right)$ is still a challenge. Common precipitation measurement methods exhibit systematic and random errors depending on the device locations and climatic conditions. Legates and DeLiberty (1993) 
concluded from their long-term study of precipitation biases in the United States that Hellmann type gauges (US standard) undercatch precipitation amounts. Undercatch is larger in case of snowfall and larger wind speeds. Wind-induced loss is seen as the main source of error (Sevruk, 1981, 1996; Yang et al., 1998; Chvíla et al., 2005; Brutsaert, 2010). Precipitation gauges are commonly installed above ground to avoid negative impact on the measurements by splash water, hail, and snow drift. However, this common gauge setup causes wind distortion and promotes the development of eddies around the device. Wind tunnel experiments with Hellmann type gauges (Nešpor and Sevruk, 1999) have shown precipitation losses of $2-10 \%$ for rain and $20-50 \%$ for snow compared to the preset precipitation amount. In general, windinduced loss increases with installation height of the device and wind speed, and it decreases with precipitation intensity (Sevruk, 1989). Intercomparison studies between different rain gauge designs of the World Meteorological Organization (WMO) have indicated that shielded devices can considerably reduce this undercatch compared to unshielded gauges, in particular for snow and mixed precipitation (Goodison et al., 1997). Further precipitation losses that affect the rain gauge measurement are evaporation of water from the gauge surface and recording mechanisms (Sevruk, 1981; Michelson, 2004). Moreover, measurement methods (e.g., condensation plates, optical methods) to estimate the contribution of rime, dew, and fog to the total precipitation exhibit a high uncertainty (Jacobs et al., 2006). A short-term lysimeter case study by Meissner et al. (2007) and a long-term investigation with a surface energy budget model calibrated with microlysimeters by Jacobs et al. (2006) show that rime, fog, and dew contribute up to $5 \%$ of the annual precipitation at a humid grassland site and are usually not captured by a standard precipitation gauge.

The eddy covariance (EC) method is one of the most established techniques to determine the exchange of water, energy, and trace gases between the land surface and the atmosphere. On the basis of the covariance between vertical wind speed and water vapor density, the EC method calculates the vertical moisture flux (and therefore ET) in high spatial and temporal resolution with relatively low operational costs. The size and shape of the measurement area (EC footprint) vary strongly with time (Finnigan, 2004). Under conditions of limited mechanical and thermal turbulence the EC method tends to underestimate fluxes (Wilson et al., 2001; Li et al., 2008). Energy balance deficits are on average found to be between 20 and $25 \%$ (Wilson et al., 2001; Hendricks Franssen et al., 2010), and therefore latent heat flux or actual evapotranspiration estimated from EC data shows potentially a strong underestimation. The energy balance closure problem can be corrected by closure procedures using the Bowen ratio. However, this is controversially discussed, especially because not only the underestimation of the land surface fluxes but also other factors like the underestimation of energy stor- age in the canopy might play a role (Twine et al., 2000; Foken et al., 2011).

As an alternative to classical rain gauges and the eddy covariance method, state-of-the-art, high-precision weighing lysimeters are able to capture the fluxes at the interface of soil, vegetation, and atmosphere (Unold and Fank, 2008). A high weighing accuracy and a controlled lower boundary condition permit high-temporal-resolution precipitation measurements at ground level, including dew, fog, rime, and snow. Additionally, $\mathrm{ET}_{\mathrm{a}}$ can be estimated with the help of the lysimeter water balance. However, the high acquisition and operational costs are a disadvantage of lysimeters. Moreover, the accuracy of lysimeter measurements is affected by several error sources. Differences in the thermal, wind, and radiation regime between a lysimeter device and its surroundings (oasis effect) (Zenker, 2003) as well as lysimeter management (e.g., inaccuracies in biomass determination) can affect the measurements. Wind or animal-induced mechanical vibrations can influence the weighing system but can be handled by accurate data processing using filtering and smoothing algorithms (Schrader et al., 2013; Peters et al., 2014). Vaughan and Ayars (2009) examined lysimeter measurement noise for data at a temporal resolution of $1 \mathrm{~min}$, caused by wind loading. They presented noise reduction techniques that rely on Savitzky-Golay (Savitzky and Golay, 1964) smoothing. Schrader et al. (2013) evaluated the different filter and smoothing strategies for lysimeter data processing on the basis of synthetic and real measurement data. They pointed out that the adequate filter method for lysimeter measurements is still a challenge, especially at high temporal resolution, due the fact that noise of lysimeter measurements varies strongly with weather conditions and mass balance dynamics. Peters et al. (2014) recently introduced a filter algorithm for high-precision lysimeters, which combines a variable smoothing time window with a noise-dependent threshold filter that accounts for the factors mentioned above. They showed that their Adaptive Window and Adaptive Threshold (AWAT) filter improves actual evapotranspiration and precipitation estimates from noisy lysimeter measurements compared to smoothing methods for lysimeter data using the Savitzky-Golay filter or simple moving averages used in other lysimeter studies (e.g., Vaughan and Ayars, 2009; Huang et al., 2012; Nolz et al., 2013; Schrader et al., 2013).

In this work, a long-term investigation to precipitation estimation with a lysimeter is presented. One of the focal points in the study is the contribution of dew and rime to the total precipitation amount. The novelty compared to the work by Meissner et al. (2007) is the length of the study and the fact that a series of six lysimeters is used. Our work allows corroborating results from Jacobs et al. (2006), who used in their long-term study a different, more uncertain measurement method.

In the literature we find several comparisons between lysimeter measurements and standard ET calculations. López-Urrea et al. (2006) found a good agreement of FAO-56 
Penman-Monteith with lysimeter data on an hourly basis. Vaughan et al. (2007) also reported a good accordance of hourly lysimeter measurements with a Penman-Monteith approach of the California Irrigation Management Information System. Wegehenkel and Gerke (2013) compared lysimeter ET with reference ET and ET estimated by a numerical plant growth model. They found that lysimeter ET overestimated actual ET, the cause being an oasis effect. On the other hand, also ET estimated by EC measurements and water budget calculations are compared in the literature. Scott (2010) found that the EC method underestimated evapotranspiration for a grassland site related to the energy balance deficit. However, only a few comparisons between ET estimated by EC and lysimeter data were found in the literature. Chávez et al. (2009) evaluated actual evapotranspiration determined by lysimeters and EC in the growing season for a cotton field site. They found a good agreement of both methods after correcting the energy balance deficit, and they suggested considering also the footprint area for EC calculations. Ding et al. (2010) found a lack of energy balance closure and underestimation of $\mathrm{ET}_{\mathrm{a}}$ by the $\mathrm{EC}$ method for maize fields. An energy balance closure based on the Bowen ratio method was able to reduce the ET underestimation. Alfieri et al. (2012) provided two possible explanations for a strong underestimation of EC-ET $\mathrm{a}_{\mathrm{a}}$ compared to lysimeter $\mathrm{ET}_{\mathrm{a}}$ : first, the energy balance deficit of the EC data, especially for those cases where EC measurements are affected by strong advection; second, deviations between the vegetation status of the lysimeter and the surrounding field. Evett et al. (2012) found an $18 \%$ underestimation of corrected EC$\mathrm{ET}_{\mathrm{a}}$ compared to $\mathrm{ET}_{\mathrm{a}}$ estimated by lysimeter and attributed the difference to differences in vegetation growth. Whereas the aforementioned studies conclude that deviations between $\mathrm{ET}_{\mathrm{a}}$ measurements are related to vegetation differences, the EC footprint, and the ability to close the energy balance gap, the uncertainties of lysimeter measurements in this context have hardly been investigated. Lysimeter $\mathrm{ET}_{\mathrm{a}}$ estimations often rely on relatively low temporal resolution due to challenges in noise reduction, which impedes a simultaneous estimation of both $P$ and $\mathrm{ET}_{\mathrm{a}}$ by lysimeters. Furthermore, studies with cost- and maintenance-intensive lysimeters are either with a few or without redundant devices, so that measurement uncertainty cannot be addressed well.

The Terrestrial Environmental Observatories (TERENO) offer the possibility of detailed long-term investigations of the water cycle components at a high spatiotemporal resolution (Zacharias et al., 2011). This study compares precipitation and evapotranspiration estimates calculated with a set of six weighing lysimeters (LYS) with nearby eddy covariance and precipitation measurements for the TERENO grassland site Rollesbroich. Additional soil moisture, soil temperature, and meteorological measurements at this TERENO test site enable a detailed analysis of differences between the different measurement techniques. The lysimeter data $\left(\mathrm{ET}_{\mathrm{a}}-\mathrm{LYS}\right)$ are processed with the AWAT filter (Peters et al., 2014), which allows a simultaneous estimation of $P$ and $\mathrm{ET}_{\mathrm{a}}$ at a high temporal resolution, and the comparison is carried out with energy-balance-corrected EC data $\left(\mathrm{ET}_{\mathrm{a}}\right.$-EC). Actual ET estimates are additionally compared to the full-form PenmanMonteith equation (Allen et al., 1998) accounting for the effects of variable grass cover height. Precipitation measurements by a classical Hellmann type tipping bucket (TB), with and without accounting for wind- and evaporation-induced loss (Richter correction), were compared with lysimeter data for 1 year (2012).

For our study, we (1) compared precipitation measurements by lysimeters and a (unshielded) standard tipping bucket device and interpreted the differences (for example, the vegetated high-precision lysimeters potentially allow for better estimates of precipitation, accounting for dew, rime, and fog); (2) compared eddy covariance and lysimeter ET estimates and tried to explain differences in estimated values; (3) tested whether a correction of the energy balance deficit for the EC method results in an $\mathrm{ET}_{\mathrm{a}}$ estimate which is close to the lysimeter method; and (4) analyzed the variability of the measurements by the six lysimeters under typical field conditions with identical configuration and management.

\section{Material and methods}

\subsection{Study site and measurement setup}

The Rollesbroich study site $\left(50^{\circ} 37^{\prime} 27^{\prime \prime} \mathrm{N}, 6^{\circ} 18^{\prime} 17^{\prime \prime} \mathrm{E}\right)$ is located in the TERENO Eifel low mountain range/Lower Rhine Valley Observatory (Germany). This sub-catchment of the river Rur has an area of 31 ha with an altitude ranging from $474 \mathrm{~m}$ to $518 \mathrm{~m}$ a.s.l. The vegetation of the extensively managed grassland site is dominated by ryegrass and smooth meadow grass. The annual mean precipitation is $1033 \mathrm{~mm}$ and the annual mean temperature $7.7^{\circ} \mathrm{C}$ (period 1981-2001); these data are obtained from a meteorological station operated by the North Rhine-Westphalian State Environment Agency (LUA NRW) at a distance of $4 \mathrm{~km}$ from the study site. Figure 1 shows a map of the study site and gives an overview of the installed measurement devices.

In 2010 a set of six lysimeters (TERENO-SoilCan project, UMS GmbH, Munich, Germany) was arranged in a hexagonal design around the centrally placed service unit, which hosts the measurement equipment and data recording devices. Each lysimeter contains silty-clay soil profiles from the Rollesbroich site and is covered with grass. The conditions at the lysimeters therefore closely resemble the ones in the direct surroundings (Fig. 2). Additionally, the spatial gap between lysimeter and surrounding soil was minimized to prevent thermal regimes which differ between the lysimeter and the surrounding field (oasis effect). Every lysimeter device has a surface of $1 \mathrm{~m}^{2}$ and a depth of $1.5 \mathrm{~m}$, and is equipped with a $50 \mathrm{~L}$ weighted leachate tank connected via a bidirectional pump to a suction rake in the bottom 

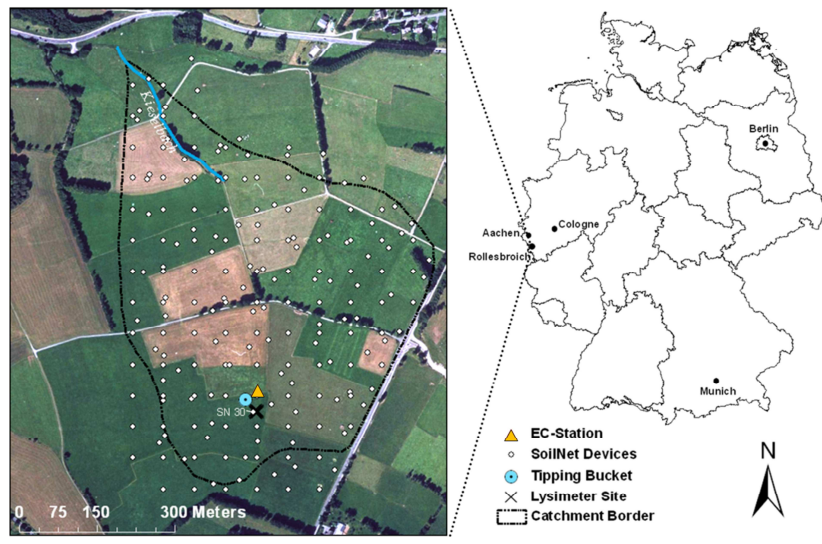

Figure 1. Overview of the Rollesbroich study site (left) showing the locations of the lysimeter, the rain gauge, the eddy covariance station, the catchment boundaries, and the SoilNet devices. All devices are arranged within a radius of $50 \mathrm{~m}$ including the nearest SoilNet device (SN30) for comparison of temperature and soil water content with the surrounding field. The map on the right shows the location of the Rollesbroich catchment in Germany.

of each lysimeter. To reproduce the field soil water regime, the lower boundary conditions are controlled by tensiometers (TS1, UMS GmbH, Munich, Germany) monitoring the soil matric potential inside the lysimeter bottom and the surrounding field. Matric potential differences between field and lysimeter are compensated by suction rakes (SIC 40, UMS $\mathrm{GmbH}$, Munich, Germany) injecting leachate tank water into the lysimeter monolith during capillary rise or removing water during drainage conditions. The weighing precision is $100 \mathrm{~g}$ for the soil monolith and $10 \mathrm{~g}$ for the leachate tank, accounting for long-term temperature variations and load alternation hysteresis effects. For short-term signal processing the relative accuracy for accumulated mass changes of soil monolith and leachate is $10 \mathrm{~g}$. For the year 2012 measurements were made every $5 \mathrm{~s}$ and averaged to get minute values. In the winter season a connection between the snow lying on the lysimeter and the surrounding snow layer potentially disturbs the weighing system. A mechanical vibration plate is engaged at all lysimeter devices to prevent this situation and is activated once every $5 \mathrm{~s}$ between two measurements. The lysimeters are also equipped with soil moisture, matric potential, and temperature sensors at different depths $(10,30,50$, and $140 \mathrm{~cm})$. Amongst others, soil temperature is determined at 10,30 , and $50 \mathrm{~cm}$ depth with PT100 sensors integrated in TS1 tensiometers (UMS GmbH, Munich, Germany). A schematic overview of the lysimeter device (Fig. 3) shows the installation locations and the different sensor types. The lysimeter site was kept under video surveillance by a camera taking a photo of the lysimeter status every hour. Further technical specifications can be found in Unold and Fank (2008).

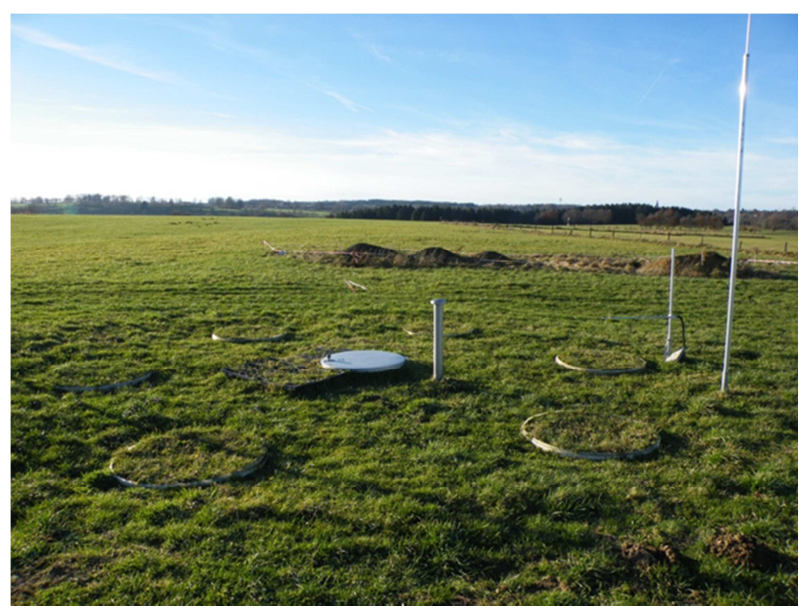

Figure 2. The lysimeter setup of the Rollesbroich study site (November 2012).

Latent and sensible heat fluxes were measured by an eddy covariance station at a distance of approximately $30 \mathrm{~m}$ from the lysimeters. The EC station $\left(50^{\circ} 37^{\prime} 19^{\prime \prime} \mathrm{N}, 6^{\circ} 18^{\prime} 15^{\prime \prime} \mathrm{E}\right.$, $514 \mathrm{~m}$ a.s.1.) is equipped with a sonic anemometer (CSAT3, Campbell Scientific, Inc., Logan, USA) at $2.6 \mathrm{~m}$ height to measure wind components. The open-path device of the gas analyzer (LI7500, LI-COR Inc., Lincoln, NE, USA) is mounted along with the anemometer at $2.6 \mathrm{~m}$ above the ground surface and measures $\mathrm{H}_{2} \mathrm{O}$ content of the air. Air pressure is measured at the processing unit of the gas analyzer at a height of $0.57 \mathrm{~m}$. Air humidity and temperature were measured by HMP45C (Vaisala Inc., Helsinki, Finland) at $2.58 \mathrm{~m}$ above the ground surface. Radiation was determined by a four-component net radiometer (NR01, Hukseflux Thermal Sensors, Delft, Netherlands). Soil heat flux was determined at $0.08 \mathrm{~m}$ depth by a pair of two HFP01 (Hukseflux Thermal Sensors, Delft, Netherlands).

Precipitation measurements are made by a standard Hellmann type TB balance rain gauge (ecoTech $\mathrm{GmbH}$, Bonn, Germany) with a resolution of $0.1 \mathrm{~mm}$ and a measurement interval of $10 \mathrm{~min}$. The measurement altitude of $1 \mathrm{~m}$ above ground is in accordance with recommendations of the German Weather Service (DWD, 1993) for areas with an elevation $>500 \mathrm{~m}$ a.s.l. and occasional heavy snowfall (WMO standard is $0.5 \mathrm{~m}$ ). The unshielded gauge was temporarily heated during wintertime to avoid freezing of the instrument.

Additional soil moisture and soil temperature measurements were carried out with a wireless sensor network (SoilNet) installed at the study site (Qu et al., 2013). The 179 sensor locations at the Rollesbroich site contain six SPADE sensors (model 3.04, sceme.de GmbH i.G., Horn-Bad Meinberg, Germany) with two redundant sensors at 5, 20, and $50 \mathrm{~cm}$ depth. Further technical details can be found in $\mathrm{Qu}$ et al. (2013). Soil water content and temperature were also measured by two sensor devices installed near the lysimeter site. 


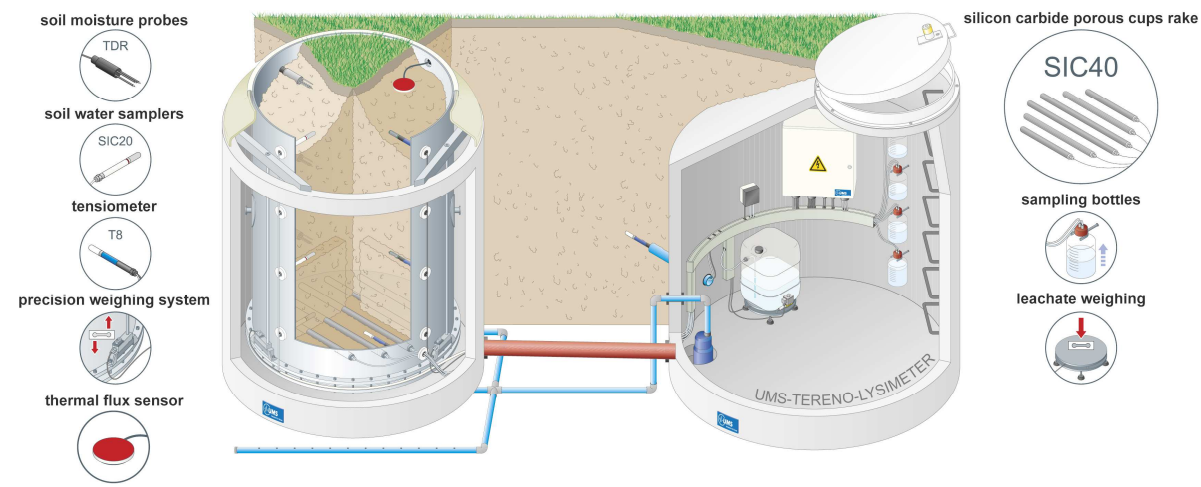

Figure 3. Schematic drawing of the lysimeter soil monolith (left) and service well (right) used in the TERENO-SoilCan project. The illustration of the lysimeter (left) shows the weighted soil column container with slots for soil moisture (TDR), temperature (SIS, TS1), matric potential sensors (SIS), soil water sampler (SIC20), and silicon porous suction cup rake (SIC40) installation inside and outside the monolith. The service well contains the weighted drainage tank and sampling tubes for each affiliated lysimeter (courtesy of UMS GmbH Munich, 2014, used by permission).

\subsection{Data processing}

\subsubsection{Lysimeter}

The lysimeter weighing data were processed in three steps:

1. elimination of outliers by an automated threshold filter;

2. smoothing of measurement signal with the AWAT filter routine on the basis of data at a temporal resolution of $1 \mathrm{~min}$;

3. estimation of hourly precipitation and evapotranspiration on the basis of the smoothed signal.

Outliers were removed from the data by limiting the maximum weight difference between two succeeding measurements for the soil column to $5 \mathrm{~kg}$ and for the leachate weight to $0.1 \mathrm{~kg}$. The lysimeter readings are affected by large random fluctuations caused by wind and other factors that influence the measurement. Therefore, the AWAT filter (Peters et al., 2014) in a second correction step was applied on the minute-wise summed leachate and on the weights for each individual lysimeter. First, the AWAT routine gathers information about signal strength and data noise by fitting a polynomial to each data point within an interval of $31 \mathrm{~min}$. The optimal order $(k)$ of the polynomial is determined by testing different polynomial orders for the given interval (i.e., $k$ : 1-6) and selecting the optimal $k$ according to Akaike's information criterion (Akaike, 1974; Hurvich and Tsai, 1989). The maximum order of $k$ is limited to 6 for the AWAT filter, preventing an erroneous fit caused by outliers. The average residual $s_{\mathrm{res}, i}$ of measured and predicted values (Eq. 1) and the standard deviation of measured values $s_{\text {dat }, i}$ (Eq. 2) lead to the quotient $B_{i}$, which gives information about the explained variance of the fit and is related to the coefficient of determination $\left(R^{2}\right)$ :

$$
\begin{aligned}
s_{\mathrm{res}, i} & =\sqrt{\frac{1}{r} \sum_{j=1}^{r}\left[y_{j}-\hat{y}_{j}\right]^{2}}, \\
s_{\mathrm{dat}, i} & =\sqrt{\frac{1}{r} \sum_{j=1}^{r}\left[y_{j}-\bar{y}\right]^{2}}, \\
B_{i} & =\frac{s_{\mathrm{res}, i}}{s_{\mathrm{dat}, i}}=\sqrt{1-R_{i}^{2}},
\end{aligned}
$$

where $y_{j}(\mathrm{M})$ is the measured data, $\hat{y}_{j}(\mathrm{M})$ the fitted value at each time interval $j, \bar{y}(\mathrm{M})$ the mean of the measurements, and $r$ the number of measurements within the given interval of data point $i . B_{i}=0$ indicates that the polynomial totally reproduces the range of data variation, in contrast to $B_{i}=1$, where nothing of the variation in the data is explained by the fitted polynomial. Second, AWAT smoothes the data using a moving average for an adaptive window width $w_{i}(\mathrm{~T})$, which is a time-dependent linear function of $B_{i}$ (Eq. 4):

$w_{i}\left(B_{i}\right)=\max \left(w_{\min }, B_{i} w_{\max }\right)$,

where $w_{\max }(\mathrm{T})$ and $w_{\min }(\mathrm{T})$ are maximum and minimum provided window width. For our study $w_{\min }$ was set to $11 \mathrm{~min} ; w_{\max }$ was $61 \mathrm{~min}$. A low $B_{i}$ requires less smoothing and therefore small time windows, whereas a $B_{i}$ close to 1 requires a smoothing interval close to the allowed $w_{\max }$. Third, AWAT applies an adaptive threshold $\delta_{i}$ (Eq. 5) to the data at each time step to distinguish between noise and signal related to the dynamics of mechanical disturbances:

$\delta_{i}=s_{\mathrm{res}, i} \cdot t_{97.5, r}$ for $\delta_{\min }<s_{\mathrm{res}, i} \cdot t_{97.5, r}<\delta_{\max }$,

where $\delta_{i}(\mathrm{M})$ is a function of the interval residuals $\left(s_{\mathrm{res}, i}\right)$ (M) (see Eq. 1) and the Student $t$ value $\left(t_{97.5, r}\right)$ for the $95 \%$ 
confidence level at each time step, $\delta_{\min }(\mathrm{M})$ is the minimum, and $\delta_{\max }(\mathrm{M})$ is the maximum provided threshold for the mass change. The product of the Student $t$ and $s_{\mathrm{res}, i}$ is a measure for the significance level of mass changes during flux calculation. Hence, the $\delta_{i}$ value indicates the range $\left( \pm s_{\text {res }, i} \cdot t_{97.5, r}\right)$, where the interval data points differ not significantly from the fitted polynomial at the $95 \%$ confidence level. Mass changes above the adaptive threshold $\delta_{i}$ are significant and interpreted as signal, whereas weight differences below $\delta_{i}$ are interpreted as noise. The adaptive threshold is limited by $\delta_{\min }$ and $\delta_{\max }$ to guarantee that (1) mass changes smaller than the lysimeter measurement accuracy are understood as remaining noise and therefore not considered for the flux calculation and (2) noise is not interpreted as signal during weather conditions which produce noisy lysimeter readings (i.e., thunderstorms with strong wind gusts). Lysimeter calibration tests with standard weights at the study site indicate a system scale resolution of $0.05 \mathrm{~kg}$. We chose a slightly higher threshold $\left(\delta_{\min }=0.055 \mathrm{~kg}\right)$ with an adequate tolerance for our TERENO lysimeter devices. For the upper threshold $\delta_{\max }=0.24 \mathrm{~kg}$ was taken, similar to the example presented by Peters et al. (2014).

For the separation of precipitation and actual evapotranspiration $\left(\mathrm{ET}_{\mathrm{a}}\right)$ AWAT assumes that increases of lysimeter and leachate weights (averaged over a period of $1 \mathrm{~min}$ ) are exclusively related to precipitation and negative differences to $\mathrm{ET}_{\mathrm{a}}$ $\left(\mathrm{M} \mathrm{T}^{-1}\right)$. Supposing that no evapotranspiration occurs during a precipitation event and assuming a fixed water density of $1000 \mathrm{~kg} \mathrm{~m}^{-3}$, precipitation $(P)\left(\mathrm{M} \mathrm{T}^{-1}\right)$ can be derived from the lysimeter water balance (Eq. 7) as

$$
\begin{array}{r}
\mathrm{ET}_{\mathrm{a}}=P-L-\frac{\mathrm{d} S_{S}}{\mathrm{~d} t}, \\
P=L+\frac{\mathrm{d} S_{S}}{\mathrm{~d} t},
\end{array}
$$

where $L$ is the amount of leachate water $\left(\mathrm{M} \mathrm{T}^{-1}\right)$ and $\mathrm{d} S_{S} / \mathrm{d} t$ is the change of soil water storage $\left(\mathrm{M} \mathrm{T}^{-1}\right)$ with time. After smoothing the fluxes at $1 \mathrm{~min}$ resolution were cumulated to hourly sums of $P$ and $\mathrm{ET}_{\mathrm{a}}$.

Although the six lysimeters have a similar soil profile, technical configuration, and management (i.e., grass cut, maintenance), differences in measured values between lysimeters are not exclusively related to random errors. Systematic weight variations may for example be caused by soil heterogeneity, mice infestation, and differences in plant dynamics. In this study precipitation measured by lysimeter and TB are compared, as well as evapotranspiration measured by lysimeter and eddy covariance. The precipitation or $\mathrm{ET}_{\mathrm{a}}$ averaged over the six redundant lysimeters is used in this comparison. We assume that the lysimeter average of six redundant lysimeter devices is the most representative estimation for the lysimeter precipitation and actual evapotranspiration (unless specified otherwise).

\subsubsection{Eddy covariance data}

Eddy covariance raw measurements were taken with a frequency of $20 \mathrm{~Hz}$, and fluxes of sensible heat $(H)$ and latent heat (LE) were subsequently calculated for intervals of $30 \mathrm{~min}$ by using the TK3.1 software package (Mauder and Foken, 2011). The complete post-processing was in line with the standardized strategy for EC data calculation and quality assurance presented by Mauder et al. (2013). It includes the application of site-specific plausibility limits and a spike removal algorithm based on median absolute deviation of raw measurements, a time lag correction for vertical wind speed with temperature and water vapor concentration based on maximizing cross-correlations between the measurements of the used sensors, a planar fit coordinate rotation (Wilczak et al., 2001), corrections for high-frequency spectral losses (Moore, 1986), the conversion of sonic temperature to air temperature (Schotanus et al., 1983), and the correction for density fluctuations (Webb et al., 1980). Processed half-hourly fluxes and statistics were applied to a three-class quality flagging scheme, based on stationarity and integral turbulence tests (Foken and Wichura, 1996) and classified as high-, moderate- and low-quality data. For this analysis only high- and moderate-quality data were used, while low-quality data were treated as missing values. To assign half-hourly fluxes with its source area, the footprint model of Korman and Meixner (2001) was applied.

Almost every eddy covariance site shows an unclosed energy balance, which means that the available energy (net radiation minus ground heat flux) is found to be larger than the sum of the turbulent fluxes (sensible plus latent heat flux) (Foken, 2008; Foken et al., 2011). In this study the energy balance deficit (EBD) was determined using a $3 \mathrm{~h}$ moving window around the measurements (Kessomkiat et al., 2013):

$\mathrm{EBD}_{3 \mathrm{~h}}=R_{\mathrm{n}-3 \mathrm{~h}}-\left(G_{3 \mathrm{~h}}+\mathrm{LE}_{3 \mathrm{~h}}+H_{3 \mathrm{~h}}+S_{3 \mathrm{~h}}\right)$,

where $R_{\mathrm{n}-3 \mathrm{~h}}$ is average net radiation $\left(\mathrm{M} \mathrm{T}^{-3}\right), G_{3 \mathrm{~h}}$ is average soil heat flux $\left(\mathrm{M} \mathrm{T}^{-3}\right), \mathrm{LE}_{3 \mathrm{~h}}$ is average latent heat flux $\left(\mathrm{M} \mathrm{T}^{-3}\right), H_{3 \mathrm{~h}}$ is average sensible heat flux $\left(\mathrm{M} \mathrm{T}^{-3}\right)$, and $S_{3 \mathrm{~h}}$ is average heat storage (canopy air space, biomass, and upper soil layer above ground heat flux plate) $\left(\mathrm{M} \mathrm{T}^{-3}\right)$. All these averages are obtained over a $3 \mathrm{~h}$ period around a particular 30 min EC measurement. The moving window of three hours is a compromise between two sources of error. First, it guarantees a relatively small impact of random sampling errors and therefore increases the reliability of the EBD calculation. Second, the relatively short interval ensures that the calculations are not too affected by non-stationary conditions. It was assumed that the energy balance deficit is caused by an underestimation of the turbulent fluxes, and therefore the turbulent fluxes are corrected according to the evaporative fraction $(\mathrm{EF})$. The $\mathrm{EF}$ was determined for a time window of 
7 days:

$\mathrm{EF}=\frac{\overline{\mathrm{LE}}_{7 \mathrm{~d}}}{\overline{\mathrm{LE}}_{7 \mathrm{~d}}+\bar{H}_{7 \mathrm{~d}}}$,

where $\overline{\mathrm{LE}}_{7 \mathrm{~d}}$ and $\bar{H}_{7 \mathrm{~d}}\left(\mathrm{M} \mathrm{T}^{-3}\right)$ are the latent and sensible heat fluxes averaged over 7 days. The chosen time period increases the reliability for EF calculation compared to single days. Dark days with small fluxes may not give meaningful results. Kessomkiat et al. (2013) investigated the impact of the time window on the calculation of the EF and found that a moving average over seven days gives good results, whereas a too-short time window of 1 day gives unstable, unreliable results.

The energy-balance-corrected latent heat flux was determined by redistribution of the latent heat on the basis of the calculated evaporative fraction:

$\mathrm{LE}_{0.5 \mathrm{~h}}^{*}=\mathrm{LE}_{0.5 \mathrm{~h}}+\mathrm{EBD}_{3 \mathrm{~h}}(\mathrm{EF})$,

where $\mathrm{LE}_{0.5 \mathrm{~h}}^{*}$ is the latent heat flux (for a certain measurement point in time, i.e., a $30 \mathrm{~min}$ period for our EC data). The EBD is added to the uncorrected LE according to the partitioning of heat fluxes in the EF. Further details on the EBD correction method can be found in Kessomkiat et al. (2013).

In this study, also the evapotranspiration $\left(\mathrm{ET}_{\mathrm{a}}-\mathrm{EC}\right)$ calculated with the original latent heat flux (not corrected for energy balance closure) will be presented for comparison. Furthermore, the most extreme case would be that the complete EBD is linked to an underestimation of the latent heat flux. Some authors argue (Ingwersen et al., 2011) that the EBD could be more related to underestimation of one of the two turbulent fluxes than the other turbulent flux. Therefore, as an extreme scenario the complete EBD is assigned to underestimation of the latent heat flux.

$\mathrm{ET}_{\mathrm{a}}-\mathrm{EC}$ is calculated from the latent heat flux according to

$\mathrm{ET}_{\mathrm{a}}=\frac{\mathrm{LE}_{\mathrm{h}}^{*}}{L\left(T_{\mathrm{h}}\right)_{\mathrm{H}_{2} \mathrm{O}} * \rho_{\mathrm{H}_{2} \mathrm{O}}}$,

where $\mathrm{ET}_{\mathrm{a}}$ is $\mathrm{ET}_{\mathrm{a}}-\mathrm{EC}\left(\mathrm{LT}^{-1}\right), \mathrm{LE}_{\mathrm{h}}^{*}$ is latent heat flux $\left(\mathrm{M} \mathrm{T}^{-3}\right), \rho$ is the density of water $\left(\mathrm{ML}^{-3}\right)$, and $L\left(T_{\mathrm{h}}\right)_{\mathrm{H}_{2} \mathrm{O}}$ is the vaporization energy $\left(\mathrm{L}^{2} \mathrm{~T}^{-2}\right)$ at a given temperature.

The lysimeters are thought to be representative of the EC footprint, although size and shape of the EC footprint are strongly temporally variable. However, the EC footprint is almost exclusively constrained to the grassland, and the lysimeters are also covered by grass.

\subsubsection{Grass reference evapotranspiration}

The measurements of $\mathrm{ET}_{\mathrm{a}}$ by the EC method and lysimeters were in this study compared with evapotranspiration calculated with full-form Penman-Monteith equation as presented by Allen et al. (1998). This approach accounts for vegetation and ground cover conditions during crop stage, considering bulk surface and aerodynamic resistances for water vapor flow. The calculations were adapted for hourly intervals according to Eq. (12):

$\mathrm{ET}_{\mathrm{PM}}=$

$\frac{0.408 \Delta\left(R_{\mathrm{n}}-G\right)+\gamma \frac{3600 \varepsilon}{T_{\mathrm{vh}} R\left(r_{\mathrm{a}} u_{2}\right)} u_{2}\left(e^{\circ}\left(T_{\mathrm{h}}\right)-e_{\mathrm{a}}\right)}{\Delta+\gamma\left(1+\frac{r_{\mathrm{s}}}{r_{\mathrm{a}}}\right)}$,

where $\mathrm{ET}_{\mathrm{PM}}$ is the hourly Penman-Monteith evapotranspiration $\left(\mathrm{L} \mathrm{T}^{-1}\right), R_{\mathrm{n}}$ is net radiation at the grass surface $\left(\mathrm{M} \mathrm{T}^{-3}\right)$, $G$ is soil heat flux density $\left(\mathrm{M} \mathrm{T}^{-3}\right), T_{\mathrm{vh}}$ is mean hourly virtual temperature $(\theta), R$ is the specific gas constant for dry air $\left(\mathrm{L}^{2} \mathrm{~T}^{-2} \theta^{-1}\right), r_{\mathrm{a}}$ is the aerodynamic resistance $\left(\mathrm{T} \mathrm{L}^{-1}\right), r_{\mathrm{s}}$ is the (bulk) surface resistance $\left(\mathrm{T} \mathrm{L}^{-1}\right), \varepsilon$ is the ratio molecular weight of water vapor (dry air) $(-), T_{\mathrm{h}}$ is mean hourly air temperature $(\theta), \Delta$ slope of the saturated vapor pressure curve at $T_{\mathrm{h}}\left(\mathrm{ML}^{-1} \mathrm{~T}^{-2} \theta^{-1}\right), \gamma$ is psychrometric constant $\left(\mathrm{ML}^{-1} \mathrm{~T}^{-2} \theta^{-1}\right), e^{\circ}\left(T_{\mathrm{h}}\right)$ is saturation vapor pressure for the given air temperature $\left(\mathrm{ML}^{-1} \mathrm{~T}^{-2}\right), e_{\mathrm{a}}$ is average hourly actual vapor pressure $\left(\mathrm{ML}^{-1} \mathrm{~T}^{-2}\right)$, and $u_{2}$ is average hourly wind speed $\left(\mathrm{L} \mathrm{T}^{-1}\right)$ at $2 \mathrm{~m}$ height. All required meteorological input parameters for calculating $\mathrm{ET}_{\mathrm{PM}}$ were taken from the EC station. The wind speed data were corrected to $2 \mathrm{~m}$ using the FAO-standard wind profile relationship of Allen et al. (1998).

We approximated aerodynamic resistance $\left(r_{\mathrm{a}}\right)$, (bulk) surface resistance $\left(r_{\mathrm{s}}\right)$, and leaf area index (LAI) with the help of grass height according to Allen et al. (2006):

$r_{\mathrm{a}}=\frac{\ln \left[\frac{z_{\mathrm{m}}-\frac{2}{3} h_{\text {plant }}}{0.123 h_{\text {plant }}}\right] \ln \left[\frac{z_{\mathrm{h}}-\frac{2}{3} h_{\text {plant }}}{0.1\left(0.123 h_{\text {plant }}\right)}\right]}{k^{2} u_{2}}$,
$r_{\mathrm{s}}=\frac{r_{\mathrm{i}}}{\mathrm{LAI}_{\text {act }}}$,
$\mathrm{LAI}_{\text {act }}=(0.3 \mathrm{LAI})+1.2=0.5\left(24 h_{\text {plant }}\right)$,

where $z_{\mathrm{m}}$ is the height of the wind measurement $(\mathrm{L}), z_{\mathrm{h}}$ is the height of the humidity measurement $(\mathrm{L}), h_{\text {plant }}$ is the grass length (L) at the lysimeter, $k$ is the von Karman constant $(-), r_{i}$ the stomatal resistance $\left(\mathrm{TL}^{-1}\right)$, and $\mathrm{LAI}_{\mathrm{act}}$ the active leaf area index taking into account that only the upper grass surface contributes to heat and vapor transfer (-). For our calculations we assume a fixed stomatal resistance for a well-watered grass cover of $100 \mathrm{~s} \mathrm{~m}^{-1}$ in accordance with Allen et al. (1998). The grass length at the lysimeters was estimated with the help of maintenance protocols and the surveillance system. Grass lengths between two measurement intervals were linearly interpolated on a daily basis.

\subsubsection{Precipitation correction}

A precipitation correction according to the method of Richter (1995) was applied (Eqs. 16, 17) on a daily basis to account for wind, evaporation, and wetting losses of the tipping 
Table 1. Site-specific wind exposition coefficient $b(-)$ and empiric precipitation type coefficient $\epsilon$ (-) for different precipitation types at an open-space gauge location.

\begin{tabular}{lrr}
\hline Precipitation type & $b$ & $\epsilon$ \\
\hline Liquid (summer) & 0.345 & 0.38 \\
Liquid (winter) & 0.34 & 0.46 \\
Mixed & 0.535 & 0.55 \\
Snow & 0.72 & 0.82 \\
\hline
\end{tabular}

bucket precipitation:

$P^{\mathrm{cor}}=P+\Delta P$,

$\Delta P=b P^{\epsilon}$,

where $P^{\text {cor }}$ is the corrected daily precipitation $\left(\mathrm{MT}^{-1}\right), P$ is the measured tipping bucket precipitation $\left(\mathrm{M} \mathrm{T}^{-1}\right), \Delta P$ the estimated precipitation deficit $\left(\mathrm{M} \mathrm{T}^{-1}\right), b$ the site-specific wind exposition coefficient (-), and $\epsilon$ the empiric precipitation type coefficient (-).

This correction method is widely used for German Weather Service stations and relies on empirical relationships of precipitation type and wind exposition, without using direct wind measurements. In order to determine both empirical coefficients, we categorized the precipitation type with the help of air temperatures on a daily basis. It was assumed that temperatures below $0^{\circ} \mathrm{C}$ result in solid precipitation, temperatures between 0 and $4^{\circ} \mathrm{C}$ give mixed precipitation, and air temperatures above $4^{\circ} \mathrm{C}$ give only liquid precipitation. Furthermore, the rain gauge is located in an open area, and the summer period was defined from May to September and the winter period from October to April. The corresponding correction coefficients were calculated according to Richter (1995) and are provided in Table 1.

\section{Results and discussion}

\subsection{Precipitation measurements}

Table 2 shows the monthly precipitation sums measured by the TB and calculated from the lysimeter balance data for the year 2012. The precipitation difference between both devices for the year 2012 is $145.0 \mathrm{~mm}$, implying a $16.4 \%$ larger average lysimeter precipitation than TB. For the individual lysimeters the yearly precipitation ranges from 996.2 to $1037.7 \mathrm{~mm}$ ( -3.0 to $+1.0 \%$ compared to the lysimeter average). This implies that the minimum and maximum precipitation differences between individual lysimeters and TB were $114.1 \mathrm{~mm}(12.9 \%)$ to $155.6 \mathrm{~mm}(17.6 \%)$, where precipitation for lysimeters was always higher than for TB. The monthly precipitation sums for the period April-October measured by the tipping bucket are smaller than the ones from the lysimeter average, and differences range between

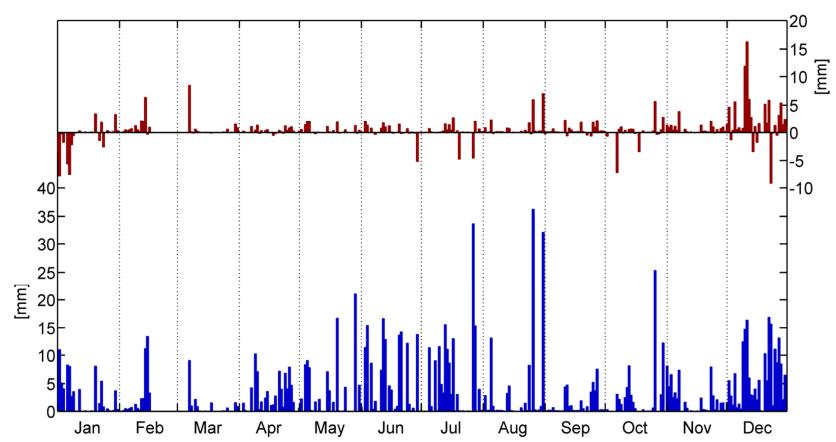

Figure 4. Daily precipitation sums of tipping bucket (blue) and difference in precipitation measurements between lysimeter and TB (red) at the Rollesbroich study site for 2012.

$1 \%$ in July and $42 \%$ in September. The winter months show higher relative differences. The highest difference was found in March 2012, when the lysimeters registered an amount of precipitation twice as large as the TB. The precipitation sums measured by lysimeter and tipping bucket correlate well on an hourly basis, especially from April to October, with $R^{2}$ varying between 0.74 (April) and 0.99 (May), but with the exception of September (0.58). For winter months the explained variance is smaller, with a minimum of $13 \%$ for February 2012.

The period April-August shows the smallest precipitation differences among the six lysimeters, with monthly values of $\pm 5 \%$ in relation to the lysimeter average. In contrast, February, September, and December exhibit the highest absolute and relative precipitation differences among lysimeters, with variations between -13 and $13 \mathrm{~mm}( \pm 35 \%)$ with respect to the mean. Figure 4 shows the absolute daily differences in precipitation between lysimeter and TB measurements. It shows that the cases where lysimeters register slightly higher monthly precipitation sums than TB are related to single heavy-rainfall events (June, July). In contrast, especially for February, the beginning of March, and the first half of December, larger fluctuations in differences between daily precipitation measured by TB and lysimeter are found, with less precipitation for TB than for lysimeters most of the days. These periods coincide with freezing conditions and frequent episodes with sleet or snowfall. According to Nešpor and Sevruk (1999) these weather conditions are typically associated with a large tipping bucket undercatch because snowflakes are easier transported with the deformed wind field around a rain gauge. The surveillance system, which is installed at the lysimeter site, gives support for these findings. For example, a sleet precipitation event on 7 March explains $70 \%(8.5 \mathrm{~mm})$ of the monthly precipitation difference between lysimeter and TB. On this day the wind speed during the precipitation event was relatively high $\left(4.4 \mathrm{~m} \mathrm{~s}^{-1}\right)$, and precipitation intensity varied between 0.6 and $2.9 \mathrm{~mm} \mathrm{~h}^{-1}$. In general, winter measurement inaccuracies can be caused by frozen sensors and snow or ice deposit on the lysimeter 
Table 2. Monthly precipitation sums for lysimeter, tipping bucket, and corrected tipping bucket data, and a comparison between the hourly precipitation values of lysimeter and uncorrected TB in terms of coefficient of determination $\left(R^{2}\right)$, root mean square error, and other statistics at the Rollesbroich study site for 2012. "Missing data \%" refers to the percentage of hourly precipitation data not available for comparison.

\begin{tabular}{|c|c|c|c|c|c|c|c|c|c|}
\hline Month & $\begin{array}{r}\text { Lysimeter } \\
\text { average } \\
(\mathrm{mm})\end{array}$ & $\begin{array}{l}\text { Min/max } \\
\text { lysimeter } \\
(\mathrm{mm})\end{array}$ & $\begin{array}{r}\text { Tipping } \\
\text { bucket } \\
(\mathrm{mm})\end{array}$ & $\begin{array}{r}\text { Tipping } \\
\text { bucket } \\
\text { corrected } \\
(\mathrm{mm})\end{array}$ & $R^{2}$ & RMSE & $\begin{array}{r}\mathrm{LYS} / \mathrm{TB} \\
\%\end{array}$ & $\begin{array}{l}\text { LYS/ } \\
\mathrm{TB}_{\text {corr }} \%\end{array}$ & $\begin{array}{r}\text { missing } \\
\text { data } \%\end{array}$ \\
\hline Jan & 70.9 & $57.6 / 79.3$ & 94.0 & 110.7 & 0.48 & 0.30 & 75.6 & 64.0 & 11.2 \\
\hline Feb & 36.2 & $31.4 / 48.9$ & 21.1 & 26.0 & 0.13 & 0.32 & 171.6 & 139.2 & 46.1 \\
\hline Mar & 17.3 & $16.2 / 18.8$ & 5.1 & 7.3 & 0.18 & 0.16 & 339.2 & 237.0 & 16.4 \\
\hline Apr & 72.5 & 71.1/74.6 & 65.3 & 78.2 & 0.90 & 0.09 & 111.0 & 92.7 & 0.0 \\
\hline May & 90.7 & $89.4 / 94.1$ & 79.3 & 88.8 & 0.99 & 0.09 & 114.4 & 114.4 & 0.0 \\
\hline Jun & 139.9 & $137.5 / 143.1$ & 134.7 & 147.2 & 0.96 & 0.21 & 103.9 & 95.0 & 0.0 \\
\hline Jul & 148.5 & $146.3 / 152.2$ & 147.0 & 159.2 & 0.95 & 0.28 & 101.0 & 93.3 & 0.0 \\
\hline Aug & 105.7 & $100.4 / 109.4$ & 84.5 & 91.9 & 0.94 & 0.15 & 125.1 & 115.0 & 0.0 \\
\hline Sep & 36.5 & 23.5/39.2 & 25.6 & 30.5 & 0.58 & 0.13 & 142.6 & 119.7 & 0.0 \\
\hline Oct & 67.5 & $65.7 / 69.5$ & 66.2 & 75.2 & 0.74 & 0.23 & 102.0 & 89.8 & 13.4 \\
\hline Nov & 55.3 & $52.7 / 56.9$ & 38.3 & 45.8 & 0.84 & 0.08 & 144.4 & 120.7 & 0.0 \\
\hline Dec & 186.0 & $178.5 / 194.4$ & 121.0 & 136.1 & 0.30 & 0.35 & 153.7 & 136.7 & 0.0 \\
\hline $\begin{array}{l}\text { Sum/ } \\
\text { mean }\end{array}$ & 1027.1 & $\begin{array}{r}996.2 / \\
1037.7\end{array}$ & 882.1 & 996.9 & 0.88 & 0.47 & 116.4 & 103.0 & 7.1 \\
\hline
\end{tabular}

surface. This situation may cause ponding effects close to the soil surface in the lysimeter and superficial runoff. In order to further address the lysimeter uncertainty, we calculated the average cumulative drainage and soil water storage with minimum and maximum ranges for the individual lysimeters (Fig. 5). The soil water storage was determined by the remaining term of the water balance on a daily basis. The total drainage averaged over the six lysimeters was $411.2 \mathrm{~mm}$ for 2012, with a variation between 385.5 and $440.4 \mathrm{~mm}$. The soil moisture storage change over the year varies between -5.1 and $28.3 \mathrm{~mm}$, with an average of $+11.2 \mathrm{~mm}$. The assessment of drainage volumes and changes in soil water storage was somewhat hampered by erroneous data related to drainage leakage (January) or system-wide shutdown due to freezing. However, the uncertainty in the water balance during those periods should have a minor effect on the short-term calculations of lysimeter $P$ and $\mathrm{ET}_{\mathrm{a}}$.

In order to explain differences in precipitation amounts between lysimeter and tipping bucket, the contribution of dew and rime to the total yearly precipitation amount was determined. The hourly data of lysimeter and TB were filtered according to meteorological criteria. First, meteorological conditions were selected which favor the formation of dew, rime, fog, and mist - namely, small precipitation events between sunset and sunrise associated with high relative humidity ( $>90 \%$ ), negative net radiation, and low wind speed $\left(<3.5 \mathrm{~m} \mathrm{~s}^{-1}\right)$. Under these meteorological conditions it is probable that dew or rime is formed after sunset and before sunrise on cloud-free days. For these days the difference in precipitation between TB and lysimeter is calculated if TB shows no precipitation signal or if the lysimeter has

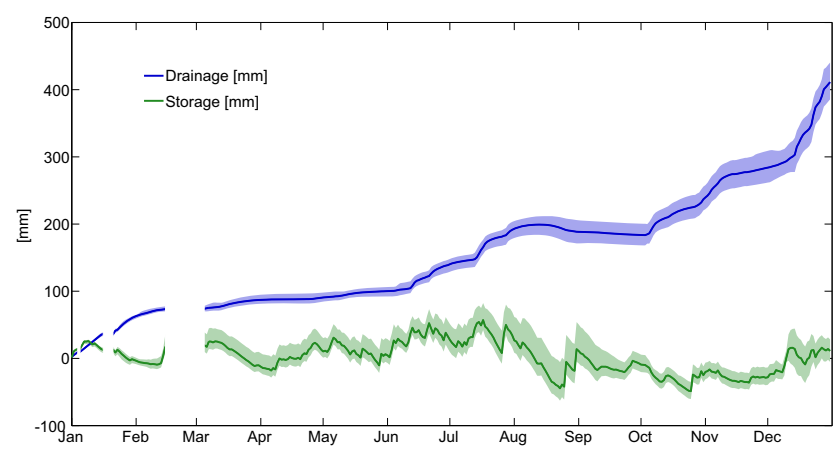

Figure 5. Cumulated average of lysimeter drainage and soil moisture storage on a daily basis. The colored areas indicate the range of minimum and maximum cumulated drainage and soil water storage for the individual lysimeters.

no precipitation signal. For the first case $(P-\mathrm{TB}=0)$ the total amount of the lysimeter precipitation is $24.5 \mathrm{~mm}$, which contributes $16.9 \%$ to the total yearly precipitation difference from the TB (and $2.4 \%$ of the yearly lysimeter precipitation). The period from April to August shows in general smaller precipitation amounts related to such situations. In contrast, likely dew and rime conditions where lysimeter precipitation is 0 have a registered amount of TB precipitation of $1.7 \mathrm{~mm}$, which is only $0.2 \%$ of the total measured TB amount for the considered period. A closer inspection of the precipitation data shows that both devices are able to capture dew and rime. However, a delay of some hours between TB and lysimeters was found. It is supposed that dew or fog precipitation was cumulating in the TB device until the resolution 


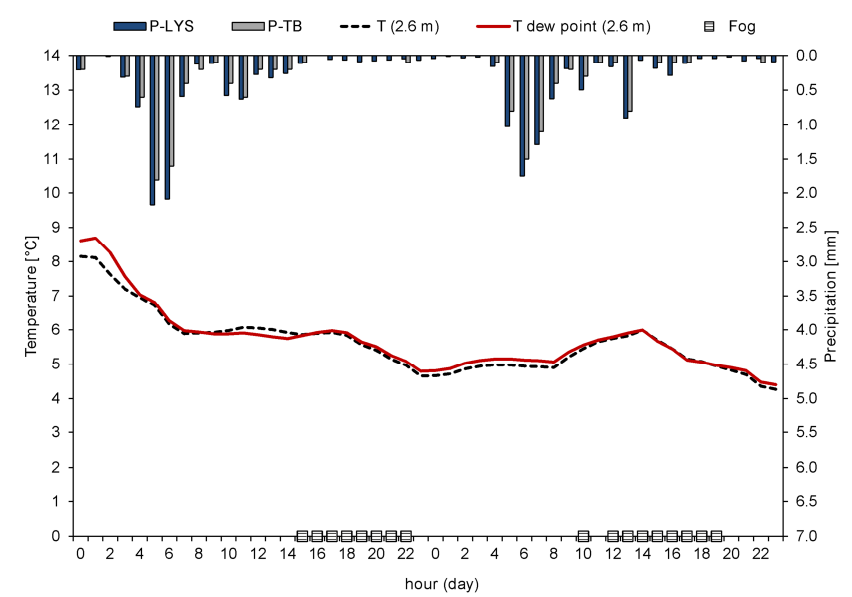

Figure 6. Precipitation, temperature, and dew point temperature from 5 to 6 May 2012 at the Rollesbroich site. The fog symbol indicates the hours with fog occurrence (detected with installed surveillance system) for the investigated period.

threshold of $0.1 \mathrm{~mm}$ was exceeded. This indicates that the TB resolution of $0.1 \mathrm{~mm}$ is too coarse to detect small dew and rime amounts in a proper temporal assignment. This confirms the expected ability of the lysimeter to measure rime and dew better than Hellmann type pluviometers or tipping bucket devices. The surveillance system was used to check whether indeed dew/rime was formed on the aforementioned days. On days which fulfilled the criteria and had air temperatures close to or below $0{ }^{\circ} \mathrm{C}$, rime was seen in the photos. For days that fulfilled the conditions and had temperatures above $0^{\circ} \mathrm{C}$, camera lenses were often covered with small droplets.

Weather conditions with drizzle or fog occur frequently at the study site. This is related to humid air masses from the Atlantic which are transported with the dominating southwestern winds and lifted against the hills in this region. The surveillance system was used to detect fog and drizzle situations during the year 2012. For those situations, a difference in precipitation between TB and lysimeters of $8 \mathrm{~mm}$ was found, which contributes $5.5 \%$ to the yearly difference of both devices. Figure 6 illustrates the example of 56 May 2012. The hourly photos of the site show drizzle, light rain, and fog for this period. For both days the air temperature is close to the dew point temperature. The precipitation difference between tipping bucket and lysimeter over this period was $4.0 \mathrm{~mm}$ ( $\Sigma$ TB: $12.8 \mathrm{~mm}$; $\Sigma$ LYS: 16.8$)$. The maximum difference was $0.5 \mathrm{~mm}$ and found at 06:00 LT on 5 May during these conditions. On 5 May in combination with fog hourly TB precipitation is often 0 and LYS mean precipitation rates are small $\left(0.02-0.2 \mathrm{~mm} \mathrm{~h}^{-1}\right)$. The comparison of individual lysimeter devices shows that not every lysimeter exceeds the predefined lower threshold of $0.055 \mathrm{~mm}$ for the AWAT filter (i.e., 5 May 15:00 LT, 6 May 01:00-03:00 LT). However, in these cases at least three lysimeters show a
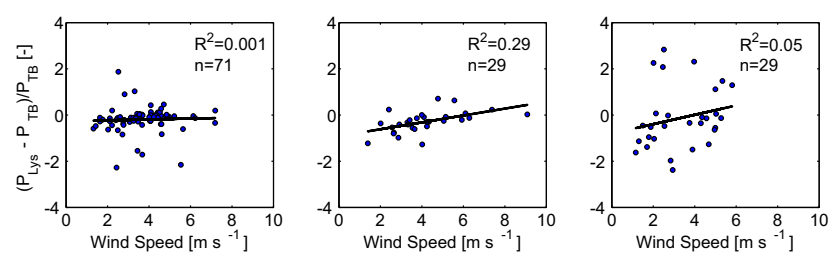

Figure 7. Relationship between wind speed and precipitation residuals relative to $\mathrm{TB}$ precipitation on a daily basis. The relationships are classified according to precipitation intensities of 1-5 mm (a), 5-10 $\mathrm{mm}$ (b), and $>10 \mathrm{~mm}$ (c). Potential rime and dew situation are excluded from the calculation.

weight increase, which supports the assumption that a real signal was measured instead of noise.

With the purpose of explaining the remaining difference in precipitation amount between TB and lysimeter, the relationship between wind speed and the precipitation differences was examined. The determined precipitation differences could in theory be explained by undercatch related to wind (Sevruk, 1981, 1996). It was checked whether correcting the tipping bucket data $\left(\mathrm{TB}_{\text {corr }}\right)$ according to the method of Richter (1995) could reduce the precipitation difference between lysimeter and TB. The total precipitation sum after correction is $996.9 \mathrm{~mm}$ for 2012 , only $3 \%$ smaller than the yearly lysimeter average and within the range of the individual lysimeters. The correction of TB data in general decreased the differences in the winter period (January-March, November-December). However, for the summer period the monthly precipitation sum of $\mathrm{TB}_{\text {corr }}$ mainly overestimated precipitation and tended to slightly increase the precipitation differences. In order to explore this relation further, we examined the correlation between wind speed and precipitation residuals and found almost no correlation (Fig. 7). A possible explanation is that other potential dew or rime situations are not properly filtered by the criteria used (e.g., dew occurs when the net radiation is slightly positive or close to 0 ). Additionally, the correlation between undercatch and wind speed is dependent on precipitation type, intensity, and drop size, for which information was limited during the investigation period. To investigate these relations, we used the classification of precipitation types as outlined before. The contribution of liquid precipitation to total yearly precipitation is $80.9 \%$ for the TB and $74.7 \%$ for the lysimeters. The relative amount of solid precipitation was also different between the two measurement methods. Whereas for the lysimeters $7.8 \%(79.7 \mathrm{~mm})$ was classified as solid precipitation, the TB had only $0.6 \%(5.6 \mathrm{~mm})$ during periods with temperature $<0{ }^{\circ} \mathrm{C}$. In relation to the total precipitation difference of $145 \mathrm{~mm}$, this means that $51 \%$ of the difference was associated with solid precipitation events and $37 \%$ with liquid precipitation events, which indicates the relatively large contribution of solid precipitation events to the total difference. The transition range $\left(0-4{ }^{\circ} \mathrm{C}\right)$ makes up $12 \%$ of the 
total difference. Moreover, it was found that $78.7 \%$ of the solid precipitation came along with small precipitation intensities $\left(<1.0 \mathrm{~mm} \mathrm{~h}^{-1}\right)$ and low wind speeds $\left(<2.0 \mathrm{~m} \mathrm{~s}^{-1}\right)$. The surveillance system allowed for further investigation of these large precipitation differences for air temperatures below 0 . The snow depth at the lysimeters and surrounding areas is also an indication of precipitation amounts, assuming that $1 \mathrm{~cm}$ snow height corresponds to $1 \mathrm{~mm}$ precipitation. This method revealed that for conditions of light to moderate snowfall ( $<4 \mathrm{~mm} \mathrm{~h}^{-1}$ precipitation intensity) the TB had a precipitation undercatch in January, February, and December of $11.4 \mathrm{~mm}$ (7.9\% of total precipitation difference). The registered precipitation amount of the lysimeter under those conditions was realistic. However, during periods where the lysimeters were completely covered by snow (e.g., 1-15 February) precipitation estimates by lysimeter (up to $16 \mathrm{~mm} \mathrm{~d}^{-1}$ difference with tipping bucket) could not be confirmed by the camera system and were most probably influenced by snow drift or snow bridges. These situations explain $35.8 \%(51.9 \mathrm{~mm})$ of the total precipitation difference for 2012. For solid precipitation events a relationship $\left(R^{2}=0.5\right)$ between precipitation differences and wind speed was found, but the number of data points was very limited $(n=7)$. For conditions of liquid precipitation no correlation was found between residuals and wind speed $\left(R^{2}<0.02\right)$.

\subsection{Comparison of evapotranspiration}

In general, the yearly sums of $\mathrm{ET}_{\mathrm{PM}}$ and $\mathrm{ET}_{\mathrm{a}}$-LYS were slightly higher than $\mathrm{ET}_{\mathrm{a}}-\mathrm{EC} ; 6.1 \%$ for $\mathrm{ET}_{\mathrm{PM}}$ and $2.4 \%$ for $\mathrm{ET}_{\mathrm{a}}$-LYS. The minimum $\mathrm{ET}_{\mathrm{a}}$ of the individual lysimeter measurements (ETa-LYSmin) is $467.1 \mathrm{~mm}$, which is $7.9 \%$ smaller than the lysimeter average $(507.4 \mathrm{~mm})$; the maximum $\left(\mathrm{ET}_{\mathrm{a}}-\mathrm{LYSmax}\right)$ is $523.1 \mathrm{~mm}(+3.1 \%)$. This indicates that in general over the year 2012 evapotranspiration was limited by energy and not by water, as actual evapotranspiration was close to a theoretical maximum value for well watered conditions as estimated by $\mathrm{ET}_{\mathrm{PM}}$. This also implies that our assumption of a stomatal resistance corresponding to well-watered conditions was justified. Water stress conditions would lead to decreased plant transpiration rates and increased stomatal resistance. Table 3 lists the evapotranspiration results of January-December 2012. In 2012 ET $_{\mathrm{PM}}$ was always close to $\mathrm{ET}_{\mathrm{a}}$-LYS and $\mathrm{ET}_{\mathrm{a}}-\mathrm{EC}$ and there are no months that $\mathrm{ET}_{\mathrm{PM}}$ is clearly larger than measured actual evapotranspiration by lysimeter and eddy covariance. Root mean square errors of hourly $\mathrm{ET}_{\mathrm{a}}$ sums vary between $0.01 \mathrm{~mm} \mathrm{~h}^{-1}$ in winter and $0.11 \mathrm{~mm} \mathrm{~h}^{-1}$ in summer months and are in phase with the seasonal ET dynamics.

We focus now on the comparison of monthly $\mathrm{ET}_{\mathrm{a}}-\mathrm{LYS}$ and $\mathrm{ET}_{\mathrm{a}}$-EC sums within the investigated period. During winter periods with low air temperatures and snowfall ET $\mathrm{E}_{\mathrm{a}} \mathrm{LYS}$ and $\mathrm{ET}_{\mathrm{a}}$-EC showed larger relative differences. For the period March to May $\mathrm{ET}_{\mathrm{a}}-\mathrm{LYS}$ and $\mathrm{ET}_{\mathrm{a}}-\mathrm{EC}$ differ approx. $6 \%$ and $\mathrm{ET}_{\mathrm{a}}$-LYS exceeds $\mathrm{ET}_{\mathrm{a}}$-EC from June to August by $12 \%$. The

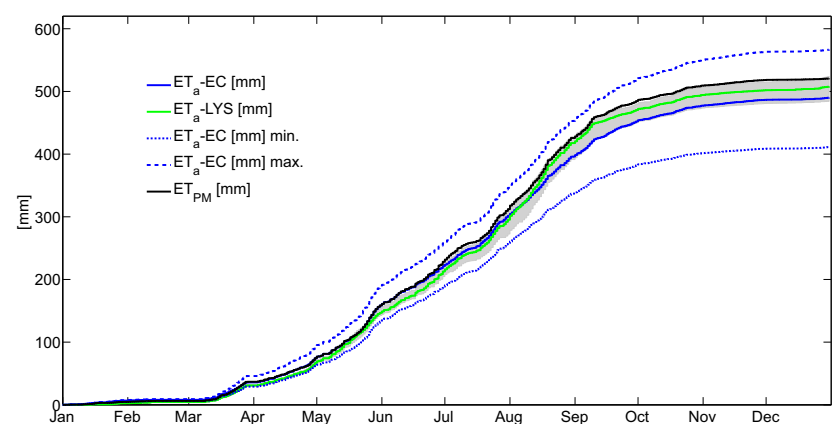

Figure 8. Cumulative $\mathrm{ET}_{\mathrm{a}}-\mathrm{LYS}, \mathrm{ET}_{\mathrm{a}}-\mathrm{EC}$ (corrected according to Bowen ratio), ETPM on hourly basis for 2012. Displayed are also $\mathrm{ET}_{\mathrm{a}}-\mathrm{EC}$ max and $\mathrm{ET}_{\mathrm{a}}-\mathrm{EC}$ min. The area in grey shows the range of minimum and maximum cumulated $\mathrm{ET}_{\mathrm{a}}$ for the individual lysimeters.

larger difference in August (23\%) explains the yearly difference between $\mathrm{ET}_{\mathrm{a}}$-EC and $\mathrm{ET}_{\mathrm{a}}$-LYS. Hourly actual evapotranspiration from lysimeter and hourly actual evapotranspiration from EC are strongly correlated, but correlation is lower in the winter months. The registered monthly ET by the different lysimeters shows the largest variations in July with amounts that are up to $14.0 \mathrm{~mm}$ lower and $8.0 \mathrm{~mm}$ higher than the ET averaged over all six lysimeters.

Figure 8 shows the cumulative curve of the daily $\mathrm{ET}_{\mathrm{a}}$ LYS and $\mathrm{ET}_{\mathrm{a}}-\mathrm{EC}$ compared to $\mathrm{ET}_{\mathrm{PM}}$ for 2012. From end of March 2012 the sums of $\mathrm{ET}_{\mathrm{a}}$-LYS and $\mathrm{ET}_{\mathrm{a}}$-EC tend to converge, but at the end of May $\mathrm{ET}_{\mathrm{a}}-\mathrm{EC}$ exceeds $\mathrm{ET}_{\mathrm{a}}$-LYS. In June and July $\mathrm{ET}_{\mathrm{a}}$-LYS and $\mathrm{ET}_{\mathrm{a}}-\mathrm{EC}$ are very similar, but in August $\mathrm{ET}_{\mathrm{a}}$-LYS is larger than $\mathrm{ET}_{\mathrm{a}}-\mathrm{EC}$. After August the difference between $\mathrm{ET}_{\mathrm{a}}$-LYS and $\mathrm{ET}_{\mathrm{a}}$-EC does not increase further. The area in grey represents the range of minimum and maximum cumulative $\mathrm{ET}_{\mathrm{a}}$-LYS, measured by individual lysimeters. Until August $\mathrm{ET}_{\mathrm{a}}-\mathrm{EC}$ and $\mathrm{ET}_{\mathrm{PM}}$ are slightly higher or close to the maximum measured $\mathrm{ET}_{\mathrm{a}}$-LYS. In August $\mathrm{ET}_{\mathrm{PM}}$ increases further, whereas $\mathrm{ET}_{\mathrm{a}}-\mathrm{EC}$ falls below the minimum lysimeter value. Additionally, Fig. 8 shows the course of the $\mathrm{ET}_{\mathrm{a}}$-EC without correction for $\mathrm{EBD}$; for $\mathrm{ET}_{\mathrm{a}}$-EC max, $\mathrm{ET}_{\mathrm{a}}$-uncorrected is ca. $411 \mathrm{~mm}$ over this period, whereas $\mathrm{ET}_{\mathrm{a}}-\mathrm{EC} \max$ is $567 \mathrm{~mm}$, which shows the large potential uncertainty of the EC data. The comparison illustrates that the application of the Bowen ratio correction to the EC data results in an actual evapotranspiration estimate close to the actual evapotranspiration from the lysimeter, whereas $\mathrm{ET}_{\mathrm{a}}$-EC-uncorrected is much smaller than the lysimeter evapotranspiration. Table 4 lists the monthly latent heat fluxes, the corrected LE fluxes (on the basis of the Bowen ratio) and the mean differences between both. It was found that the absolute difference is between $29.8 \mathrm{~W} \mathrm{~m}^{-2}$ (August 2012) and $3.2 \mathrm{~W} \mathrm{~m}^{-2}$ (February 2012). The EBD ranges from 12.6-24.2\% for the period April to September. The yearly maximum was found in February with $36.9 \%$. EB deficits are site-specific, but these findings confirm the 
Table 3. Monthly $\mathrm{ET}_{\mathrm{a}}$ (by lysimeter and EC), $\mathrm{ET}_{\mathrm{PM}}$ sums, and $R^{2}$ between different ET data products on an hourly basis for 2012. "Missing data \%" refers to the percentage of hourly ET data $\left(\mathrm{ET}_{\mathrm{a}}-\mathrm{EC}, \mathrm{ET}_{\mathrm{a}}-\mathrm{LYS}\right)$ between sunrise and sunset not available for comparison. Hence, the total yearly ET amount is reduced by ca. $18 \%$ compared to gap-free ET estimations.

\begin{tabular}{|c|c|c|c|c|c|c|c|c|c|c|c|c|c|c|}
\hline & \multicolumn{13}{|c|}{2012} & \multirow[b]{2}{*}{ Mean } \\
\hline & Jan & Feb & Mar & Apr & May & Jun & Jul & Aug & Sep & Oct & Nov & Dec & Sum & \\
\hline $\mathrm{ET}_{\mathrm{a}}-\mathrm{EC}(\mathrm{mm})$ & 5.2 & 1.3 & 27.8 & 38.4 & 84.3 & 62.7 & 80.3 & 94.2 & 56.0 & 25.2 & 9.3 & 3.6 & 488.3 & \\
\hline $\mathrm{ET}_{\mathrm{PM}}(\mathrm{mm})$ & 3.9 & 1.5 & 30.5 & 37.5 & 84.2 & 69.7 & 84.0 & 113.5 & 58.9 & 24.6 & 9.0 & 2.5 & 519.8 & \\
\hline $\mathrm{ET}_{\mathrm{a}}-\mathrm{LYS}(\mathrm{mm})$ & 2.5 & 2.2 & 26.4 & 35.6 & 80.2 & 65.7 & 82.7 & 121.7 & 52.7 & 23.9 & 7.6 & 5.9 & 507.4 & \\
\hline $\operatorname{Min} / \max$ & $2.1 /$ & $1.3 /$ & $25.9 /$ & $34.4 /$ & $75.2 /$ & $62.1 /$ & $67.8 /$ & $116.8 /$ & $49.6 /$ & $21.9 /$ & $6.8 /$ & $3.0 /$ & $467.1 /$ & \\
\hline $\mathrm{ET}_{\mathrm{a}}-\mathrm{LYS}(\mathrm{mm})$ & 2.7 & 3.1 & 26.8 & 37.6 & 85.2 & 68.2 & 91.0 & 125.2 & 58.8 & 27.1 & 8.9 & 8.7 & 523.1 & \\
\hline$R^{2} \mathrm{ET}_{\mathrm{a}}-\mathrm{EC}-\mathrm{ET}_{\mathrm{a}}-\mathrm{LYS}$ & 0.02 & 0.02 & 0.82 & 0.76 & 0.79 & 0.84 & 0.86 & 0.86 & 0.66 & 0.66 & 0.39 & 0.06 & & 0.81 \\
\hline$R^{2} \mathrm{ET}_{\mathrm{a}}-\mathrm{LYS}-\mathrm{ET}_{\mathrm{PM}}$ & 0.13 & 0.00 & 0.87 & 0.82 & 0.86 & 0.91 & 0.89 & 0.92 & 0.78 & 0.70 & 0.41 & 0.08 & & 0.89 \\
\hline$R^{2} \mathrm{ET}_{\mathrm{a}}-\mathrm{EC}-\mathrm{ET}_{\mathrm{PM}}$ & 0.12 & 0.00 & 0.94 & 0.93 & 0.95 & 0.90 & 0.89 & 0.88 & 0.88 & 0.82 & 0.73 & 0.44 & & 0.91 \\
\hline Missing data $\%$ & 33.2 & 36.9 & 8.1 & 23.5 & 21.5 & 26.5 & 21.9 & 12.9 & 14.0 & 25.8 & 25.0 & 45.3 & 24.5 & \\
\hline
\end{tabular}

Table 4. Measured mean monthly latent heat fluxes and corrections for EBD for 2012.

\begin{tabular}{lrrrr}
\hline Month & $\begin{array}{r}\text { Mean LE } \\
\left(\mathrm{W} \mathrm{m}^{-1}\right)\end{array}$ & $\begin{array}{r}\text { Mean LE corr. } \\
\left(\mathrm{W} \mathrm{m}^{-1}\right)\end{array}$ & $\begin{array}{r}\text { Differences } \\
\text { LE corr. }- \text { LE }\end{array}$ & $\begin{array}{r}\text { Difference mean } \\
\text { LE corr. }- \text { LE \% }\end{array}$ \\
\hline Jan & 21.9 & 29.8 & 7.9 & 36.2 \\
Feb & 8.7 & 11.9 & 3.2 & 36.9 \\
Mar & 78.1 & 94.0 & 15.9 & 20.4 \\
Apr & 86.4 & 101.8 & 15.3 & 17.7 \\
May & 138.7 & 164.6 & 25.9 & 18.7 \\
Jun & 111.8 & 125.8 & 14.0 & 12.6 \\
Jul & 136.3 & 157.2 & 20.9 & 15.3 \\
Aug & 151.6 & 181.4 & 29.8 & 19.6 \\
Sep & 104.0 & 129.2 & 25.2 & 24.2 \\
Oct & 61.3 & 79.6 & 18.3 & 29.9 \\
Nov & 24.4 & 32.1 & 7.7 & 31.4 \\
Dec & 22.0 & 28.3 & 6.3 & 28.5 \\
\hline Sum/mean & 78.8 & 94.6 & 15.9 & 24.3 \\
\hline
\end{tabular}

importance of EC data correction as suggested by Chávez et al. (2009).

In order to explain the differences between $\mathrm{ET}_{\mathrm{PM}}, \mathrm{ET}_{\mathrm{a}^{-}}$ $\mathrm{EC}$, and $\mathrm{ET}_{\mathrm{a}}-\mathrm{LYS}$, we investigated the variations in radiation, vegetation, and temperature regime as well as their impact on ET in more detail. The albedo could be estimated according to the measured outgoing shortwave radiation at the EC station divided by the incoming shortwave radiation, also measured at the EC station. The yearly mean albedo is 0.228 , which is close to the assumed albedo of 0.23 for grassland. However, some periods (i.e., periods with snow cover) have a much higher albedo. Although albedo variations between different vegetation growth stages at different fields at the study site were considered as an explanation for differences in $\mathrm{ET}_{\mathrm{a}}$, we assume similar albedo for $\mathrm{ET}_{\mathrm{a}}-\mathrm{EC}$ and $\mathrm{ET}_{\mathrm{a}}-\mathrm{LYS}$ measurement due to the central location of of the radiation measurements between the relevant fields.

The grass length is related to the LAI, which impacts water vapor flow at the leaf surface. Under well-watered conditions more surface for plant transpiration leads in general to higher transpiration rates by decreasing the bulk surface resistance. Figure 9 shows that the grass length measured at the Rollesbroich site is up to $80 \mathrm{~cm}$ before cutting. Unfortunately, grass height measurements are not available for the lysimeters but only for the surrounding fields. It is assumed, on the basis of information from the video surveillance system, that grass heights generally are in good agreement between lysimeters (lysimeter site) and the surrounding field (lysimeter field), which allows a reconstruction of the grass length illustrated in Fig. 9. However, the grass harvesting dates of lysimeters and surrounding field deviate in August and September and are given for the lysimeters in Fig. 9.

Figure 10 illustrates the differences of the measured daily $\mathrm{ET}_{\mathrm{a}}$ sums between lysimeter and EC. High positive and negative differences up to $2.1 \mathrm{~mm} \mathrm{day}^{-1}$ were found from March 2012 to September 2012. In general, the differences of $\mathrm{ET}_{\mathrm{a}}-\mathrm{LYS}$ and $\mathrm{ET}_{\mathrm{PM}}$ show smaller fluctuations than the differences of $\mathrm{ET}_{\mathrm{a}}-\mathrm{EC}$ and $\mathrm{ET}_{\mathrm{PM}}$. It was found that lysime- 


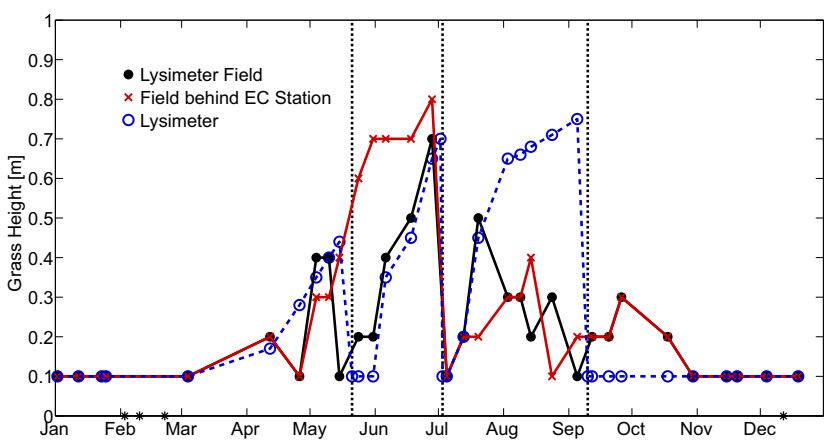

Figure 9. Grass heights at the lysimeter field, the lysimeter devices, and the field behind the EC station for 2012. The grass length at the lysimeter devices was reconstructed by comparing grass length measurements of the lysimeter field with the observations of the surveillance system. The star $(*)$ indicates the presence of a snow cover. Grass cutting dates on lysimeter devices are marked by dashed lines.

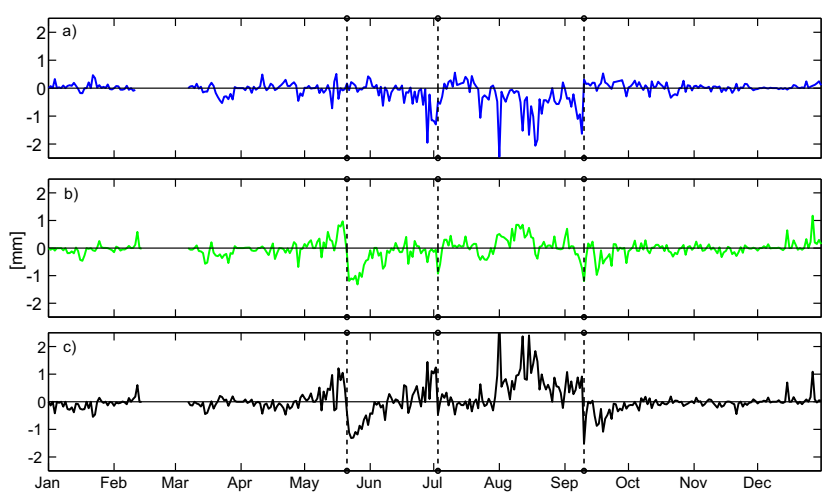

Figure 10. Differences between daily ET for 2012. Displayed are $\mathrm{ET}_{\mathrm{a}}-\mathrm{EC}-\mathrm{ET}_{\mathrm{PM}}(\mathbf{a}), \mathrm{ET}_{\mathrm{a}}-\mathrm{LYS}-\mathrm{ET}_{\mathrm{PM}}(\mathbf{b})$, and $\mathrm{ET}_{\mathrm{a}}-\mathrm{LYS}_{\mathrm{B}}-\mathrm{ET}_{\mathrm{a}}$ $\mathrm{EC}(\mathbf{c})$. The dashed lines indicate harvest at lysimeters.

ter harvesting affects the differences between $\mathrm{ET}_{\mathrm{a}}$-LYS and $\mathrm{ET}_{\mathrm{PM}} / \mathrm{ET}_{\mathrm{a}}-\mathrm{EC}$. The differences were positive before harvesting and negative after harvesting, indicating $\mathrm{ET}_{\mathrm{a}}$ reduction due to the grass cutting effects. For the period from 21 May to 3 July, a period with high grass length differences (Fig. 9) between the lysimeter site and the field behind the EC station, $\mathrm{ET}_{\mathrm{a}}$ differences $\left(\mathrm{ET}_{\mathrm{a}}-\mathrm{EC}-\mathrm{ET}_{\mathrm{a}}-\mathrm{LYS}\right)$ and grass length differences show a good correlation $\left(R^{2}=0.58\right)$, which is illustrated in Fig. 11. During the period with maximum grass length difference (24 May-1 June) $\mathrm{ET}_{\mathrm{a}}-\mathrm{EC}$ is $26 \%$ higher than $\mathrm{ET}_{\mathrm{a}}$-LYS. The differences between $\mathrm{ET}_{\mathrm{a}}-\mathrm{EC}$ and $\mathrm{ET}_{\mathrm{PM}}$ do not show such a significant correlation with grass heights, although the relationship in August is in correspondence with the differences of $\mathrm{ET}_{\mathrm{a}}-\mathrm{EC}$ and $\mathrm{ET}_{\mathrm{a}}-\mathrm{LYS}$. This could be related to the EC footprint, because the EC station is centrally located in between the two investigated fields with different grass lengths. The EC footprint might also include other surrounding fields with different grass heights. Eighty percent

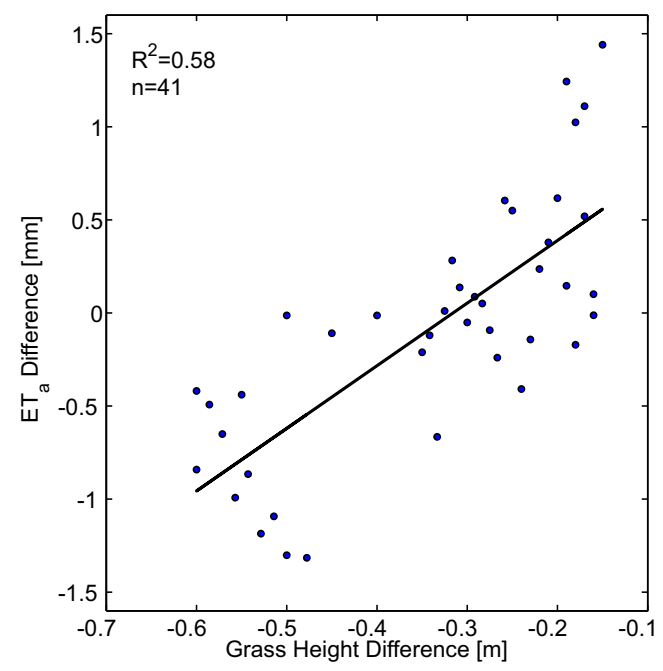

Figure 11. Relationship between grass length difference (between the lysimeters and the field behind the $\mathrm{EC}$ device) and $\mathrm{ET}_{\mathrm{a}}$ difference measured by lysimeters and EC station from 21 May to 3 July.
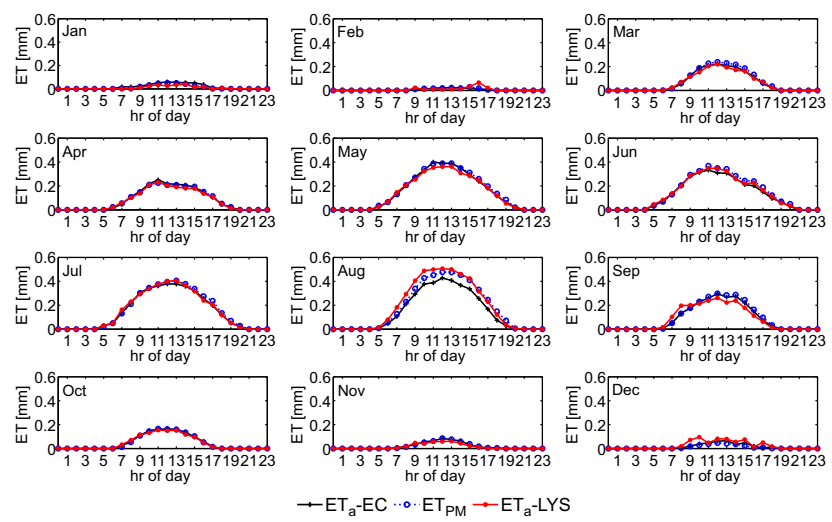

Figure 12. Mean daily cycle of $\mathrm{ET}_{\mathrm{a}}-\mathrm{LYS}, \mathrm{ET}_{\mathrm{a}}-\mathrm{EC}$ and $\mathrm{ET}_{\mathrm{PM}}$ for 2012.

of the EC footprint is located within a radius of $100 \mathrm{~m}$ of the EC tower, and $70 \%$ in a radius of $40 \mathrm{~m}$, which is the approximate lysimeter distance. Therefore, the $\mathrm{ET}_{\mathrm{a}}$-EC estimations represent a spatial mean of a wider area, where cutting effects are averaged compared to the lysimeter point measurements. Figure 12 shows the mean hourly $\mathrm{ET}_{\mathrm{a}}$ rates of lysimeter and $\mathrm{EC}$ as well as the $\mathrm{ET}_{\mathrm{PM}}$ for 2012. In general, the daily courses and the daily maxima of $\mathrm{ET}_{\mathrm{a}}-\mathrm{LYS}, \mathrm{ET}_{\mathrm{PM}}$, and $\mathrm{ET}_{\mathrm{a}}-\mathrm{EC}$ correspond well. $\mathrm{ET}_{\mathrm{a}}-\mathrm{EC}$ shows higher peaks at noon in May and September compared to $\mathrm{ET}_{\mathrm{a}}-\mathrm{LYS}$, but it corresponds well to $\mathrm{ET}_{\mathrm{PM}}$. In contrast, $\mathrm{ET}_{\mathrm{a}}$-LYS exhibits the highest rates from June to August. The absence of a harvest of the lysimeter in August and the first days in September (in contrast to the surrounding fields) leads to potentially increased lysimeter $\mathrm{ET}_{\mathrm{a}}$ measurements as compared to the surroundings due to an island position. 

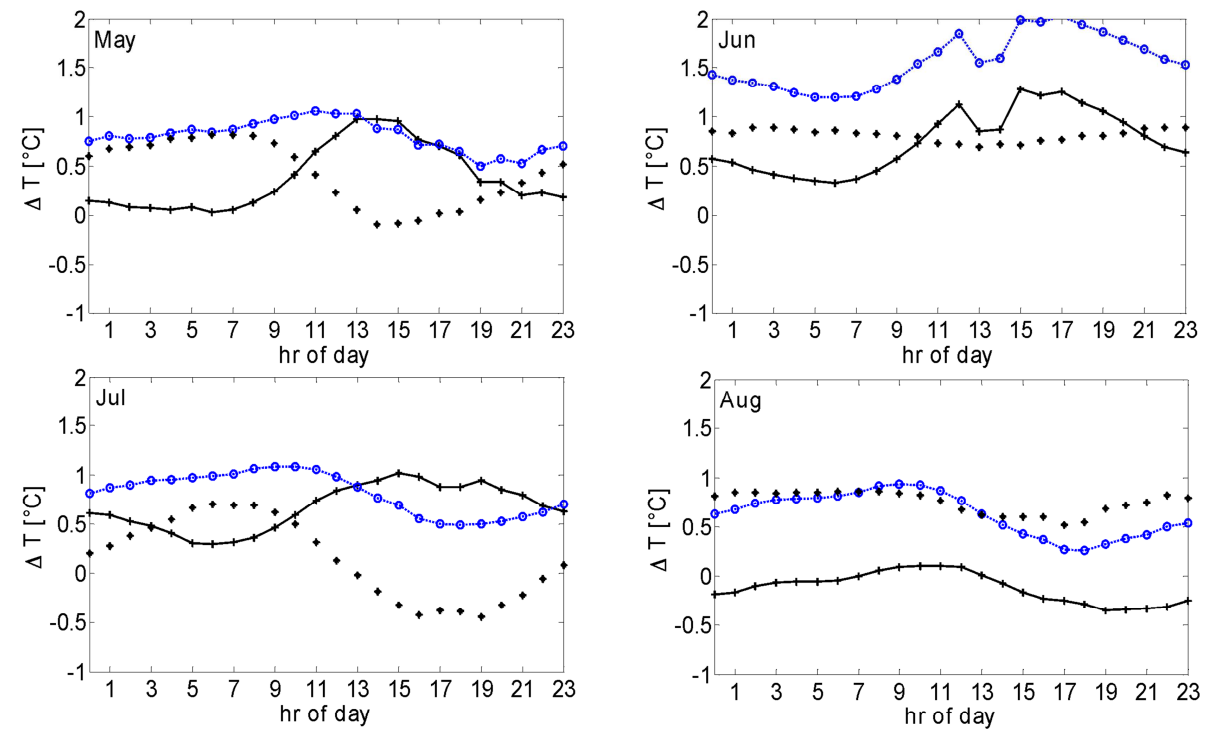

$+\Delta \mathrm{T}\left[{ }^{\circ} \mathrm{C}\right]\left(\right.$ Lysimeter-SoilNet N30) $\cdots \cdot \cdots \Delta \mathrm{T}\left[{ }^{\circ} \mathrm{C}\right]\left(\right.$ Lysimeter-SoilNet) $* \Delta \mathrm{T}\left[{ }^{\circ} \mathrm{C}\right]$ (SoilNet N3O-SoilNet)

Figure 13. Differences in daily mean soil temperature (averaged over the six lysimeters), a nearby SoilNet device (SN30), and the mean of all available SoilNet devices located at the study site.

In order to examine whether lysimeter measurements could have been affected by a soil temperature regime different from the field, the temperature regimes of the lysimeters were compared to the field temperature. Figure 13 shows the daily mean soil temperature differences between the lysimeters, a nearby SoilNet device (SN30), and the mean of all available SoilNet devices installed at the southern study site. SoilNet temperatures were measured $5 \mathrm{~cm}$ below surface; lysimeter temperature measurements were conducted with SIS sensors at $10 \mathrm{~cm}$ depth. The temperature differences between the lysimeter, the nearby SoilNet device, and the SoilNet mean are less than $1 \mathrm{~K}$, which is also the range of variation of the SoilNet device with respect to the SoilNet mean. In general the temperature differences increase until noon and then decrease again. Positive differences from May to July indicate higher lysimeter soil temperatures than the surroundings. However, a clear indicator for a bias caused by an oasis effect in the lysimeter measurements was not found. Feldhake and Boyer (1986) described the effect of soil temperature on evapotranspiration for different grass types, which allows an estimation of $\mathrm{ET}_{\mathrm{a}}$ increase caused by a differing lysimeter temperature regime. They showed that daily $\mathrm{ET}_{\mathrm{a}}$ rates can increase with an increase of soil temperature (i.e., daily Bermuda grass $\mathrm{ET}_{\mathrm{a}}$ rate increases from 4.3 to $6.4 \mathrm{~mm} \mathrm{day}^{-1}(49 \%)$ for a soil temperature increase from 13 to $29^{\circ} \mathrm{C}$ ). We used this linear relationship to roughly estimate the effect on $\mathrm{ET}_{\mathrm{a}}$ for the period May-August on a daily basis. For this period the soil temperature measured with $\mathrm{SN}(30)$ for daylight hours ranged between 9.5 and $15.1^{\circ} \mathrm{C}$ and between 9.3 and $15.5^{\circ} \mathrm{C}$ for the lysimeter mean (SIS sensors). The mean difference is $0.67 \mathrm{~K}$. This results in a total $\mathrm{ET}_{\mathrm{a}}$ in- crease of $8.8 \mathrm{~mm}$, or $2.5 \%$ in relation to the total $\mathrm{ET}_{\mathrm{a}}-\mathrm{LYS}$ of $349 \mathrm{~mm}$ on the basis of hourly ET. Therefore, the effect of increased soil temperature in the lysimeter is most probably limited, but not negligible.

\section{Conclusions}

This study compares evapotranspiration and precipitation estimates calculated using a set of six redundant weighable lysimeters with nearby eddy covariance and precipitation measurements at a TERENO grassland site in the Eifel (Germany) for 1 year (2012). The lysimeter data at a temporal resolution of $1 \mathrm{~min}$ are processed with the AWAT filter (Peters et al., 2014), which takes into account the lysimeter noise due to random fluctuations caused by changing weather conditions. Additional precipitation measurements were conducted with a classical unshielded Hellmann type tipping bucket and compared with lysimeter data. For the $\mathrm{ET}_{\mathrm{a}}$ comparison eddy covariance data are corrected for the energy balance deficit using the Bowen ratio method. Additionally, evapotranspiration and the evapotranspiration according to the full-form Penman-Monteith equation were calculated.

The estimated hourly precipitation amounts derived by lysimeter and tipping bucket data show significant differences, and the total precipitation measured by the lysimeter is $16.4 \%$ larger than the tipping bucket amount. The relative differences in the monthly precipitation sums are small in the summer period, whereas high differences are found during the winter season. The winter months with solid precipitation exhibit the lowest correlations between lysimeter 
and tipping bucket amounts. Precipitation was measured by six different lysimeters, and yearly amounts for individual lysimeters showed variations of -3.0 to $1.0 \%$ compared to the yearly precipitation mean over all lysimeters. An additional comparison with corrected tipping bucket precipitation measurements according to the method of Richter (1995) shows in general a decrease of the monthly and yearly difference, which was $3 \%$ after correction. In order to explain the differences in precipitation between the devices, the contribution of dew, rime, and fog to the yearly precipitation was analyzed. This was done by filtering the data for typical weather conditions like high relative humidity, low wind speed, and negative net radiation, which promote the development of dew and rime. For the identified cases a check was made with a visual surveillance system as to whether dew/rime was visible. During these conditions the lysimeter shows clearly larger precipitation amounts than the TB, which explains $16.9 \%$ of the yearly precipitation difference. Fog and drizzling rain conditions, additionally identified with the help of the on-site camera system, explain another 5.5\% of the yearly precipitation differences. These findings indicate an improved ability of the lysimeters to measure dew and rime as well as fog and drizzling rain. The remaining $78 \%$ of the precipitation difference between lysimeters and tipping bucket is strongly related to snowfall events, as under those conditions large differences were found. Lysimeter precipitation measurements are affected by a relatively high measurement uncertainty during winter weather conditions, similar to TB and other common measurement methods. Thus, the limitations for the lysimeter precipitation measurements during those periods require further investigation. We found that, during conditions where the lysimeters were completely covered by snow, lysimeter records were unreliable and contributed $36 \%$ of the total precipitation difference.

Actual evapotranspiration measured by $\mathrm{ET}_{\mathrm{a}}-\mathrm{EC}$ and $\mathrm{ET}_{\mathrm{a}}{ }^{-}$ LYS showed a good correspondence for 2012, with larger relative differences and low correlations in winter in contrast to high correlations and smaller relative differences in summer. The variability of $\mathrm{ET}_{\mathrm{a}}$ of the individual lysimeters in relation to the lysimeter average was -7.9 to $3.1 \%$ in 2012 with larger absolute differences in summer. Both $\mathrm{ET}_{\mathrm{a}}-\mathrm{EC}$ and $\mathrm{ET}_{\mathrm{a}}$-LYS were close to the calculated Penman-Monteith evapotranspiration $\left(\mathrm{ET}_{\mathrm{PM}}\right)$, which indicates that evapotranspiration at the site was energy limited. The differences between $\mathrm{ET}_{\mathrm{a}}-\mathrm{LYS}, \mathrm{ET}_{\mathrm{a}}-\mathrm{EC}$, and $\mathrm{ET}_{\mathrm{PM}}$ were mainly related to harvesting management at the study site. A relationship between grass length at the lysimeter and differences between $\mathrm{ET}_{\mathrm{PM}}$ and $\mathrm{ET}_{\mathrm{a}}$-LYS was found. Variable grass cutting dates for different fields around the EC station and the lysimeter harvest lead to differences in actual evapotranspiration up to $2.1 \mathrm{~mm} \mathrm{day}^{-1}$ for periods with larger grass length discrepancies.

The correction of the energy balance deficit with the Bowen ratio method resulted in $\mathrm{ET}_{\mathrm{a}}-\mathrm{EC}$ which was close to $\mathrm{ET}_{\mathrm{a}}-\mathrm{LYS}$. When the correction was not applied, $\mathrm{ET}_{\mathrm{a}}-\mathrm{EC}$ was
$16 \%$ smaller than for the case where it was applied. In contrast, if the EB deficit was completely attributed to the latent heat flux, $\mathrm{ET}_{\mathrm{a}}$ was $15.7 \%$ larger than for the default case. These results point to the importance of adequate EC data correction.

Acknowledgements. This research is based on data provided by the research infrastructures of TERENO and TERENO-SoilCan. We thank the Transregio32 for contributing data from the Rollesbroich study site and would like to acknowledge H. Rützel, W. Benders, F. Engels, L. Fürst, W. Küppers, D. Dolfus, and M. Kettler for the realization and maintenance of the research facilities. We also thank Andre Peters for providing the AWAT software. We further thank the "Arbeitskreis Lysimeterdatenauswertung" for the stimulating discussions.

The article processing charges for this open-access publication were covered by a Research Centre of the Helmholtz Association.

Edited by: P. Gentine

\section{References}

Akaike, H.: A new look at statistical model identification, IEEE Trans. Auto. Control, 19, 716-723, doi:10.1109/TAC.1974.1100705, 1974.

Alfieri, J. G., Kustas, W. P., Prueger, J. H., Hipps, L. E., Evett, S. R., Basara, J. B., Neale, C. M. U., French, A. N., Colaizzi, P., Agam, N., Cosh, M. H., Chavez, J. L., and Howell, T. A.: On the discrepancy between eddy covariance and lysimetry-based surface flux measurements under strongly advective conditions, Adv. Water Resour., 50, 62-78, doi:10.1016/j.advwatres.2012.07.008, 2012.

Allen, R. G., Pereira, L. S., Raes, D., and Smith, M.: Crop evapotranspiration-Guidelines for computing crop water requirements-FAO Irrigation and drainage paper 56, FAO, Rome, 9, 300, 1998.

Allen, R. G., Pruitt, W. O., Wright, J. L., Howell, T. A., Ventura, F., Snyder, R., Itenfisu, D., Steduto, P., Berengena, J., Yrisarry, J. B., Smith, M., Pereira, L. S., Raes, D., Perrier, A., Alves, I., Walter, I., and Elliott, R.: A recommendation on standardized surface resistance for hourly calculation of reference ETo by the FAO56 Penman-Monteith method. Agr. Water Manage., 81, 122, doi:10.1016/j.agwat.2005.03.007, 2006.

Brutsaert, W.: Hydrology: An Introduction/Wilfried Brutsaert, 5th print. Edn., Univ. Press, Cambridge, XI, 605 pp., 2010.

Chávez, J., Howell, T., and Copeland, K.: Evaluating eddy covariance cotton ET measurements in an advective environment with large weighing lysimeters, Irrig. Sci., 28, 35-50, doi:10.1007/s00271-009-0179-7, 2009.

Chvíla, B., Sevruk, B., and Ondrás, M.: The wind-induced loss of thunderstorm precipitation measurements, Atmos. Res., 77, 2938, doi:10.1016/j.atmosres.2004.11.032, 2005.

Deutscher Wetterdienst (DWD): Richtlinie für automatische Klimastationen, Offenbach am Main, 1993.

Ding, R., Kang, S., Li, F., Zhang, Y., Tong, L., and Sun, Q.: Evaluating eddy covariance method by large-scale weighing lysimeter 
in a maize field of northwest China, Agr. Water Manage., 98, 87-95, doi:10.1016/j.agwat.2010.08.001, 2010.

Evett, S. R., Schwartz, R. C., Howell, T. A., Louis Baumhardt, R., and Copeland, K. S.: Can weighing lysimeter ET represent surrounding field ET well enough to test flux station measurements of daily and sub-daily ET?, Adv. Water Resour., 50, 7990, doi:10.1016/j.advwatres.2012.07.023, 2012.

Feldhake, C. M. and Boyer, D. G.: Effect of soil temperature on evapotranspiration by $\mathrm{C} 3$ and $\mathrm{C} 4$ grasses, Agr. Forest Meteorol., 37, 309-318, doi:10.1016/0168-1923(86)90068-7, 1986.

Finnigan, J.: The footprint concept in complex terrain, Agr. Forest Meteorol., 127, 117-129, doi:10.1016/j.agrformet.2004.07.008, 2004.

Foken, T. and Wichura, B.: Tools for quality assessment of surfacebased flux measurements, Agr. Forest Meteorol., 78, 83-105, doi:10.1016/0168-1923(95)02248-1, 1996.

Foken, T.: The energy balance closure problem: An overview, Ecol. Appl., 18, 1351-1367, doi:10.1890/06-0922.1, 2008.

Foken, T., Aubinet, M., Finnigan, J. J., Leclerc, M. Y., Mauder, M., and Paw U, K. T.: Results Of A Panel Discussion About The Energy Balance Closure Correction For Trace Gases, B. Am. Meteorol. Soc., 92, 13-18, doi:10.1175/2011bams3130.1, 2011.

Goodison, B. E., Louie, P. Y. T., and Yang, D.: The WMO solid precipitation measurement intercomparison. World Meteorological Organization-Publications-WMO TD, 65-70, 1997.

Hendricks Franssen, H. J., Stöckli, R., Lehner, I., Rotenberg, E., and Seneviratne, S. I.: Energy Balance Closure of Eddy-Covariance Data: A Multisite Analysis for European Fluxnet Stations, Agr. Forest Meteorol., 150, 1553-1567, doi:10.1016/j.agrformet.2010.08.005, 2010.

Huang, W., Zhang, C., Xue, X., and Chen, L.: A Data Acquisition System Based on Outlier Detection Method for Weighing Lysimeters, in: Computer and Computing Technologies in Agriculture V, edited by: Li, D. and Chen, Y., IFIP Advances in Information and Communication Technology, Springer Berlin Heidelberg, 471-478, 2012.

Hurvich, C. and Tsai, C.: Regression and time series model selection in small samples, Biometrika, 76, 297-307, doi:10.1093/biomet/76.2.297, 1989.

Ingwersen, J., Steffens, K., Högy, P., Warrach-Sagi, K., Zhunusbayeva, D., Poltoradnev, M., Gäbler, R., Wizemann, H. D., Fangmeier, A., Wulfmeyer, V., and Streck, T.: Comparison of Noah simulations with eddy covariance and soil water measurements at a winter wheat stand, Agr. Forest Meteorol., 151, 345-355, doi:10.1016/j.agrformet.2010.11.010, 2011.

Jacobs, A. F. G., Heusinkveld, B. G., Wichink Kruit, R. J., and Berkowicz, S. M.: Contribution of dew to the water budget of a grassland area in the Netherlands, Water Resour. Res., 42, W03415, doi:10.1029/2005wr004055, 2006.

Kessomkiat, W., Hendricks Franssen, H. J., Graf, A., and Vereecken, H.: Estimating random errors of eddy covariance data: An extended two-tower approach, Agr. Forest Meteorol., 171-172, 203-219, doi:10.1016/j.agrformet.2012.11.019, 2013.

Kohnke, H., Davidson, J. M., and Dreibelbis, F. R.: A survey and discussion of lysimeters and a bibliography on their construction and performance, U. S. Govt. print. off., Washington, D.C., p. 68, 1940.
Kormann, R. and Meixner, F.: An Analytical Footprint Model For Non-Neutral Stratification, Bound.-Lay. Meteorol., 99, 207-224, doi:10.1023/a:1018991015119, 2001.

Legates, D. R. and DeLiberty, T. L.: Precipitation measurement biases in the United States, JAWRA J. Am. Water Resour. Assoc., 29, 855-861, doi:10.1111/j.1752-1688.1993.tb03245.x, 1993.

Li, S., Kang, S., Zhang, L., Li, F., Zhu, Z., and Zhang, B.: A comparison of three methods for determining vineyard evapotranspiration in the arid desert regions of northwest China, Hydrol. Process., 22, 4554-4564, doi:10.1002/hyp.7059, 2008.

López-Urrea, R., Olalla, F. M. d. S., Fabeiro, C., and Moratalla, A.: An evaluation of two hourly reference evapotranspiration equations for semiarid conditions, Agr. Water Manage., 86, 277-282, doi:10.1016/j.agwat.2006.05.017, 2006.

Mauder, M. and Foken, T.: Documentation and Instruction Manual of the Eddy-Covariance Software Package TK3. Arbeitsergebnisse/Universität Bayreuth, Abteilung Mikrometeorologie, 2011.

Mauder, M., Cuntz, M., Drüe, C., Graf, A., Rebmann, C., Schmid, H. P., Schmidt, M., and Steinbrecher, R.: A strategy for quality and uncertainty assessment of long-term eddycovariance measurements, Agr. Forest Meteorol., 169, 122-135, doi:10.1016/j.agrformet.2012.09.006, 2013.

Meissner, R., Seeger, J., Rupp, H., Seyfarth, M., and Borg, H.: Measurement of dew, fog, and rime with a high-precision gravitation lysimeter, J. Plant Nutri. Soil Sci., 170, 335-344, doi:10.1002/jpln.200625002, 2007.

Michelson, D. B.: Systematic correction of precipitation gauge observations using analyzed meteorological variables, J. Hydrol., 290, 161-177, doi:10.1016/j.jhydrol.2003.10.005, 2004.

Moore, C. J.: Frequency response corrections for eddy correlation systems. Bound.-Lay. Meteorol., 37, 17-35, doi:10.1007/bf00122754, 1986.

Nešpor, V. and Sevruk, B.: Estimation of Wind-Induced Error of Rainfall Gauge Measurements Using a Numerical Simulation, J. Atmos. Ocean. Technol., 16, 450-464, doi:10.1175/15200426(1999)016<0450:eowieo>2.0.co;2, 1999.

Nolz, R., Kammerer, G., and Cepuder, P.: Interpretation of lysimeter weighing data affected by wind, J. Plant Nutri. Soil Sci., 176, 200-208, doi:10.1002/jpln.201200342, 2013.

Peters, A., Nehls, T., Schonsky, H., and Wessolek, G.: Separating precipitation and evapotranspiration from noise - a new filter routine for high-resolution lysimeter data, Hydrol. Earth Syst. Sci., 18, 1189-1198, doi:10.5194/hess-18-1189-2014, 2014.

Qu, W., Bogena, H. R., Huisman, J. A., and Vereecken, H.: Calibration of a Novel Low-Cost Soil Water Content Sensor Based on a Ring Oscillator, Vadose Zone J., 12, 1-12, doi:10.2136/vzj2012.0139, 2013.

Richter, D.: Ergebnisse methodischer Untersuchungen zur Korrektur des systematischen Messfehlers des HellmannNiederschlagsmessers Berichte des Deutschen Wetterdienstes, 194, 1995.

Savitzky, A. and Golay, M.: Smoothing and Differentiation of Data by Simplified Least Squares Procedures, Anal. Chem., 36, 16271639, doi:10.1021/ac60214a047, 1964.

Schotanus, P., Nieuwstadt, F. T. M., and de Bruin, H. A. R.: Temperature measurement with a sonic anemometer and its application to heat and moisture fluxes. Bound.-Lay. Meteorol., 26, 81-93, doi:10.1007/bf00164332, 1983. 
Schrader, F., Durner, W., Fank, J., Gebler, S., Pütz, T., Hannes, M., and Wollschläger, U.: Estimating Precipitation and Actual Evapotranspiration from Precision Lysimeter Measurements, Procedia Environ. Sci., 19, 543-552, doi:10.1016/j.proenv.2013.06.061, 2013.

Scott, R. L.: Using watershed water balance to evaluate the accuracy of eddy covariance evaporation measurements for three semiarid ecosystems, Agr. Forest Meteorol., 150, 219-225, doi:10.1016/j.agrformet.2009.11.002, 2010.

Sevruk, B.: Methodische Untersuchungen des systematischen Messfehlers der Hellmann-Regenmesser im Sommerhalbjahr in der Schweiz. Mitteilungen Nr. 52, Versuchsanstalt für Wasserbau, Hydrologie und Glaziologie, ETH Zürich, 299 Book pp., 1981.

Sevruk, B.: Wind induced measurement error for high-intensity rains. Proc. International Workshop on Precipitation Measurement, WMO Tech. Document 328, St. Moritz, Switzerland, 199204, 1989.

Sevruk, B.: Adjustment of tipping-bucket precipitation gauge measurements, Atmos. Res., 42, 237-246, doi:10.1016/01698095(95)00066-6, 1996.

Strangeways, I.: A history of rain gauges, Weather, 65, 133-138, doi:10.1002/wea.548, 2010.

Twine, T. E., Kustas, W. P., Norman, J. M., Cook, D. R., Houser, P. R., Meyers, T. P., Prueger, J. H., Starks, P. J., and Wesely, M. L.: Correcting eddy-covariance flux underestimates over a grassland, Agr. Forest Meteorol., 103, 279-300, doi:10.1016/S01681923(00)00123-4, 2000.

Unold, G. and Fank, J.: Modular Design of Field Lysimeters for Specific Application Needs, Water Air Soil Pollution, Focus, 8, 233-242, doi:10.1007/s11267-007-9172-4, 2008.

Vaughan, P. J. and Ayars, J.: Noise Reduction Methods for Weighing Lysimeters, J. Irrig. Drain. Eng., 135, 235-240, doi:10.1061/(ASCE)0733-9437(2009)135:2(235), 2009.

Vaughan, P. J., Trout, T. J., and Ayars, J. E.: A processing method for weighing lysimeter data and comparison to micrometeorological $\mathrm{ET}_{0}$ predictions, Agr. Water Manage., 88, 141-146, doi:10.1016/j.agwat.2006.10.008, 2007.
Webb, E. K., Pearman ,G. I., and Leuning, R.: Correction of flux measurements for density effects due to heat and water vapour transfer, Q. J. Roy. Meteorol. Soc., 106, 85-100, doi:10.1002/qj.49710644707, 1980.

Wegehenkel, M. and Gerke, H. H.: Comparison of real evapotranspiration measured by weighing lysimeters with simulations based on the Penman formula and a crop growth model, J. Hydrol. Hydromechan., 61, 161-172, doi:10.2478/johh-2013-0021, 2013.

Wilczak, J., Oncley, S., and Stage, S.: Sonic Anemometer Tilt Correction Algorithms, Bound.-Lay. Meteorol., 99, 127-150, doi:10.1023/a:1018966204465, 2001.

Wilson, K. B., Hanson, P. J., Mulholland, P. J., Baldocchi, D. D., and Wullschleger, S. D.: A comparison of methods for determining forest evapotranspiration and its components: sap-flow, soil water budget, eddy covariance and catchment water balance, Agr. Forest Meteorol., 106, 153-168, doi:10.1016/S01681923(00)00199-4, 2001.

Yang, D., Goodison, B. E., Metcalfe, J. R., Golubev, V. S., Bates, R., Pangburn, T., and Hanson, C. L.: Accuracy of NWS 8" Standard Nonrecording Precipitation Gauge: Results and Application of WMO Intercomparison, J. Atmos. Ocean.Technol., 15, 54-68, doi:10.1175/15200426(1998)015<0054:AONSNP>2.0.CO;2, 1998.

Zacharias, S., Bogena, H., Samaniego, L., Mauder, M., Fuß, R., Pütz, T., Frenzel, M., Schwank, M., Baessler, C., ButterbachBahl, K., Bens, O., Borg, E., Brauer, A., Dietrich, P., Hajnsek, I., Helle, G., Kiese, R., Kunstmann, H., Klotz, S., Munch, J. C., Papen, H., Priesack, E., Schmid, H. P., Steinbrecher, R., Rosenbaum, U., Teutsch, G., and Vereecken, H.: A Network of Terrestrial Environmental Observatories in Germany, Vadose Zone J., 10, 955-973, doi:10.2136/vzj2010.0139, 2011.

Zenker, T.: Verdunstungswiderstände und Gras- Referenz- verdunstung: Lysimeteruntersuchungen zum Penman-Monteith-Ansatz im Berliner Raum, PhD thesis, Berlin University of Technology, Germany, 2003. 